\title{
A Descriptive Study to Assess the Knowledge Regarding Substance Abuse Among B.Sc. Nursing Students
}

\author{
Jyoti Laxmi Chetty \\ Assistant Professor, Dayananada Sagar University, Bengaluru, Karnataka, India
}

\section{ABSTRACT}

Adolescence is the most important and labile phase of human life cycle. Approximately $18-20 \%$ of Indian population constitute of age group between 13-24 years. These futures citizens are at great risk for early initiation to drugs and other psychoactive substances. The present study is an attempt to "Assess the knowledge regarding substance abuse among B.Sc students in DayanandaSagar University, Bangalore."Objectives• To assess the level of knowledge regarding substance abuse among BSC Nursing students. ${ }^{-}$To assess the knowledge regarding the ill effects of substance abuse among the study subjects..$^{-} \quad$ To determine the association between the knowledge of substance abuse among study subjects with their selected demographic variables. The research approach and research design adopted for the study was descriptive. Simple random sampling was used to select the sample of this study. The sample consists of 40 students, in between age group of 16- 24 years. Data were collected by using structured knowledge questionnaire. The questionnaire had 2 sections. Section 1 comprised of demographic data and section 2 on knowledge aspects of substance abuse. Data collected were analysed by using descriptive statistics. Results of the study revealed that majority of the student that is $52.5 \%$ had inadequate knowledge regarding substance abuse. The mean knowledge score was high in 19-21 years age group (50\%), females (72.5), and students residing in paying guest $(57.5 \%)$, students who got $70 \%$ and above last year's percentage (40\%).

IThe ?2 analysis revealed that there was significant relationship between gender, percentage of marks obtained last year, type of family, living of status of parents, monthly pocket money received, educational status of parents, how often do you read literature related to drugs, how often do you listen or watch programmes related to substance abuse. There was no relationship between knowledge and other socio demographics like age, year of study, religion, place of stay and monthly family income. On the basis of study we can draw the following conclusion majority of the student had inadequate knowledge related to substance abuse. The mean knowledge score was high in 19-21 years age group (50\%), females (72.5), and students residing in paying guest $(57.5 \%)$, students who got $70 \%$ and above last year's percentage (40\%).

\section{Key words: SUBSTANCE ABUSE, DRUGS}

\section{INTRODUCTION}

Substance abuse has become a global phenomenon. It has affected almost every country, although its extent and characteristics differ from region to region. It is estimated that at least 40 million people throughout the world are regular substance or drug abusers. The problems of drug abuse are localized especially in the urban, semi-urban and along the border areas of India. The period of adolescence is a vulnerable period in the life of an individual. The increased vulnerability in this period related to psychological factors like curiosity, poor impulse control, run away from reality, psychological distress and so forth. The social factors like peer influence, lack of clear identity, and self or intra-familial conflict also expose the adolescent to substance abuse

The problem of substance abuse is a significant problem among adolescents in our societies as the problem is increasing day by day due to various factors like easy availability and rapid socioeconomic and demographic changes. Recent studies have shown that the drug addicts registered for treatment and rehabilitation of various treatment centers are mostly adolescents and youth students ${ }^{5}$. In terms of initiating substance abuse a significant percentage of drug abuser $(83 \%)$ has started using drug and other 
substances between 16-20 years followed by under 15 year.

\section{NEED FOR THE STUDY:}

Substance abuse is a serious public health problem that affects almost every community and family in some way.

Each year substance abuse results in around 40 million serious illnesses or injuries among people in the States ${ }^{7}$. Teens who abuse drugs with needles increase their risk of blood-borne diseases like HIV, AIDS and Hepatitis B and C.

Nevertheless, experimentation with substances, particularly alcohol and tobacco, is progressively more common behavior among college students. There is casual relationship between alcohol consumption and more than 60 types of diseases and injury worldwide alcoholism estimated to cause about $20 \%-30 \%$ of esophageal cancer, liver cancer, and cirrhosis of liver, homicide, epilepsy and motor vehicle accidents. Worldwide 1.8 million deaths and 58.3 million DALY attributed to the use of alcohol.

A study was conducted to assess the awareness among students to determine relationship of knowledge and selected variables in 40 B.Sc $1^{\text {st }}$ year and $2^{\text {nd }}$ year students of College of Nursing Sciences DayanandaSagar University using a structured knowledge questionnaire. Non probability convenient sampling was used. The study result showed that nursing students' knowledge of drug abuse was inadequate. No significant relationship was found between knowledge, sex and mass media.

Substance abuse is a growing problem in India, defined as a disease in 1956 by the World Health Organization and the American Psychiatric Association, substance abuse is "the illicit consumption of any naturally occurring or pharmaceutical substance for the purpose of changing the way in which a person feels, thinks or behaves, without understanding or taking into consideration the damaging physical and mental side-effects that are caused.

Use of tobacco, alcohol and other substances is a worldwide problem which affects many children and adolescents. Early initiation of substance abuse is usually associated with a poor prognosis and a lifelong pattern of irresponsible behavior. The hope that simple information given through educational programs will be sufficient to prevent drug dependence is frequently expressed, however, there is no evidence to support it. Knowledge with regards to consequence of substance use among adolescents will be helpful to prevent them from initiating and continuing its use. Therefore keeping in focus the research question- present study aims to find -what is the level of knowledge regarding the substance abuse among adolescents.

Several risk factors had been identified among adolescents and early adults substance abuse which include family conflicts, academic difficulties, depression, conduct disorder, peer pressure, ignorance, relief from stress, increased energy, to relive pain, escape from reality, they may take stimulants to keep alert, cocaine for feeling of excitement, athletes and body builders may take anabolic steroids to increase muscle mass. The common substance abuse among adolescents in India are tobacco and alcohol but use of illicit and stronger drugs like cannabis, opium, or even intravenous use of drugs such as heroin have also been reported. A new trend has emerged in drug and substance abuse with children now taking a cocktail of drugs through injection, and often sharing the same needle, which increases their vulnerability to HIV infection.

\section{OBJECTIVES}

\section{STATEMENT OF PROBLEM}

A descriptive study to assess the knowledge regarding substance abuse among B.Sc. Nursing students.

\section{OPERATIONAL DEFINITIONS}

Assess: It refers to evaluate the knowledge of the adolescents regarding the ill effect of substance abuse.

Knowledge: Ability to give correct answer to the question ask by the researcher regarding substance abuse.

Substance: A substance is a solid, powder, liquid, or gas with particular properties. A pattern of repeated drug or alcohol use that often interferes with health work or social relationships.

Abuse: It is the improper usage or treatment of entity often to improperly or unfairly gain benefit. To use something for the wrong purpose in a way that is harmful or morally wrong. 
Substance Abuse: Substance abuse, also known as drug abuse, is a patterned use of a substance (drug) in which the user consumes the substance in amounts or with methods neither approved nor supervised by medical professionals. Drug use and abuse is as old as mankind itself. Human beings have always had a desire to eat or drink substances that make them feel relaxed, stimulated or euphoric.

\section{OBJECTIVES}

The objectives are based on the statement of the problem the statement of problem is A descriptive study to assess the knowledge regarding substance abuse among B.Sc. Nursing students, DayanandaSagar University, College of Nursing Sciences, Bengaluru.

1. To assess the level of knowledge regarding substance abuse among BSC Nursing students.

2. To assess the knowledge regarding the ill effects of substance abuse among the study subjects.

3. To determine the association between the knowledge of substance abuse among study subjects with their selected demographic variables.

\section{HYPOTHESIS:}

H1: There will be significant association between the knowledge scores of B.Sc Nursing students with selected demographic variables.

\section{ASSUMPTIONS}

1. Most of the students may have inadequate knowledge regarding substance abuse.

\section{DELIMITATIONS}

$>$ The study is limited to the students who are between the age group 16-24 years of age in DayanandaSagar University, College of Nursing Sciences.

$>$ Study duration is delimited for 1 week.

Study is delimited to those who are available at the time of data collection

\section{CONCEPTUAL FRAMEWORK}

A concept is an abstract idea or mental image of phenomena or reality (Kozier 1989)

A Conceptual framework is the processor of a theory. It provides broad perspectives for nursing practice research and education. Conceptual Framework plays a several interrelated roles in the progress of science.
Their overall purpose is to make scientific findings meaningful and generalizable.

Polit and hungler(1989)describe conceptual framework as a group of mental images or concepts that are related but the relationship is notn explicit.

The conceptual framework of the study is based on the system theory of SisterCallista Roy.

\section{Sister Callista Roy Systems Theory:}

The focus of Roy's model is the set of process by which a person adapts to environmental stresses. Each person is a unifed bio psycho social system in constant interaction with changing environment. When the demands of the environmental stimuli are too grate or the persons adaptive mechanism are too low the persons behavior response are in effective for coping.

Roy vies the person as an adaptive system that functions as a whole through interdependence of its parts. The system consists of input control process output and feedback. Input is stimuli from the external environment and the internal self, including information (stimuli) from the cognator and regulator mechanisms.

The control processes include both biological and psychological coping mechanisms of the person, as well as cognator and regulatory responses. Output is the adaptive and ineffective behavioral responses of the person. Feedback is information regarding then behavioral responses that is conveyed as input in the system.

In the present study these concepts can be explained as follows:

\section{Input}

Input consists of characteristics and conditions of people and the resources. The individuals own personality affects their learning as well as aids in influencing others. In this study input refers to the source of information regarding substance abuse, though their life experiences by increasing with the age being male/female, religious guidance and family financial background.

\section{Throughput}

Process refers to the differential operational procedures of the programme. They include assessment of the existing knowledge and attitude of 
adolescents regarding psychoactive substance use. The assessment of knowledge is essential because the cognitive process have their own motivational or dynamics force which forms, attitude and directs behavior.

\section{Output}

After processing through assessment the systems output in form of behavior, directing with acquired knowledge and attitude. If there is adequate knowledge, it leads to positive attitude. Inadequate knowledge leads to negative attitude in turn causes drug abusive behavior. This can rectified by means of education and attitude development programs.

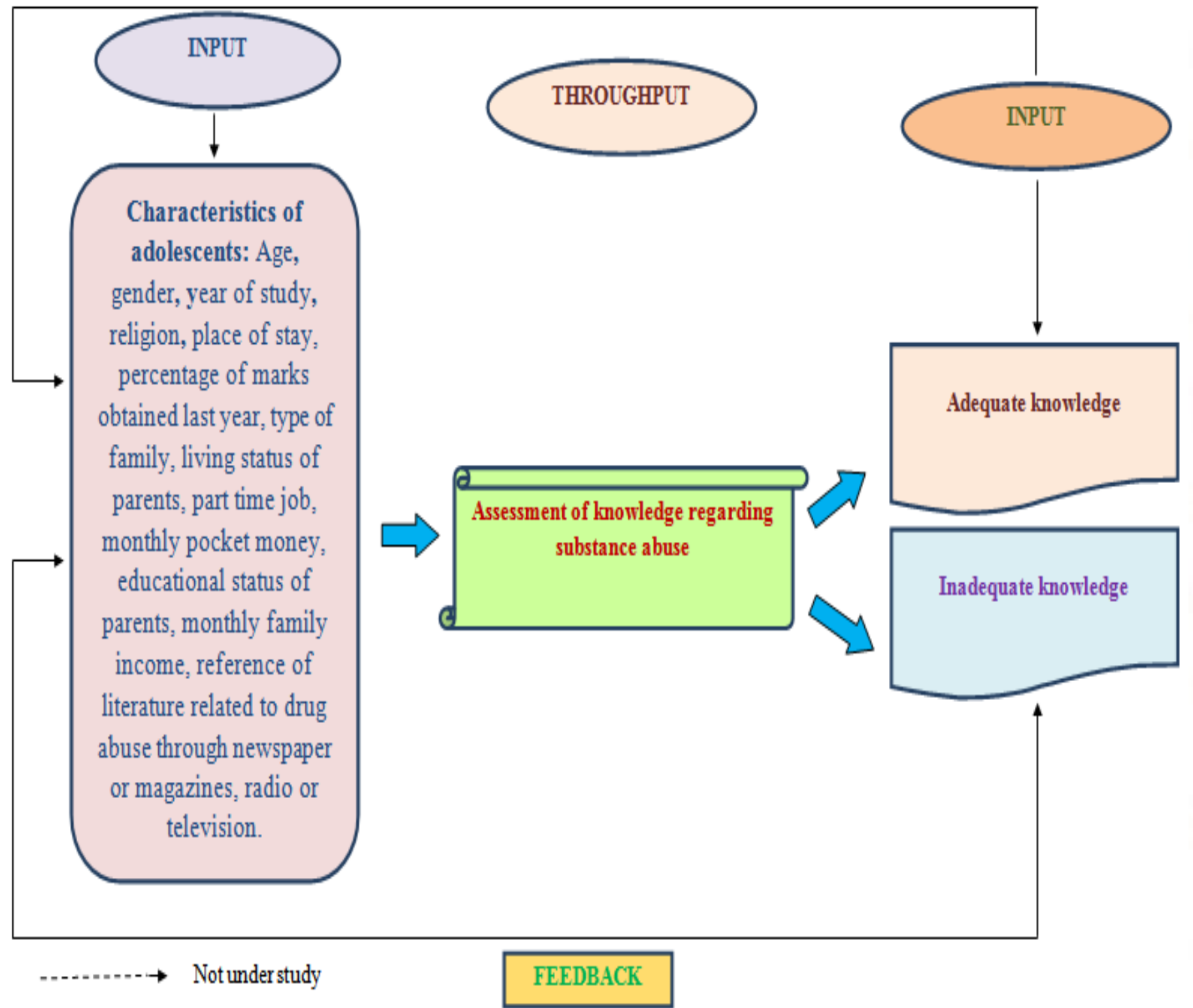

Figure 1: Conceptual framework based on the system model by Sister Callista Roy

\section{CRITERIA FOR SAMPLE SELECTION}

\section{Inclusion criteria:}

$>$ Students who were in between the age group of 16-24 years

College students who were present at the time of study

> Students who were willing to participate

\section{Exclusion criteria:}

$>$ Students who were absent at the time of study.
$>$ College students who were not willing to participate.

Students below the age of 16 years and above 24 year

\section{DEVELOPMENT OF THE TOOL}

After an extensive review of literature, discussion with the guide, the Structured Knowledge questionnaire for assessing knowledge of nursing students towards substance abuse was devised. The 
items were then subjected to content validation, pre testing and estimation of reliability.

\section{DESCRIPTION OF THE TOOL}

In the present study the tool consists of three sections:

1. Part A

2. Part B

\section{Part A: Demographic data}

Consists of items in the socio demographic variables such as age, sex, year of study, religion, place of stay, percentage of marks obtained last year, type of family, living status of parents, any part time job of the nursing student, pocket money received per month, educational status of parents, monthly family income, reading newspaper or magazine and watching programs related to substance abuse on radio or television.

\section{Part B: Structured Questionnaire for assessing knowledge regarding substance abuse.}

Consists of 30 structured items which consists of questions related to substance abuse. Maximum score of each item is 1 , hence the total score of the item is 30 .

\section{Tool construction}

The tool was constructed by collecting information from the sources like psychiatry textbook, review of literature on substance abuse, articles on substance abuse and internet.

The scores may be interpreted as follows:

1. $<30 \%$ : Low level of knowledge (less than 9)

2. $30 \%-75 \%$ : Moderate level of knowledge $(9-22)$

3. $>75 \%$

: Adequate level of knowledge

(more than 22)

\section{CONTENT VALIDITY}

Validity refers to the degree to which an instrument measures what it is intended to measure. ${ }^{12}$

To obtain validity of the tool, the prepared tool with objectives, operational definition, hypotheses were submitted to experts. Recommendations given were included in the tool. The tool was presented and finalized by the research committee of DayanandaSagar University, College of Nursing Sciences.

\section{RELIABILITY OF THE TOOL}

Reliability is defined as the degree of consistency or dependability with which an instrument measures the attribute it is designed to measure. ${ }^{12}$

Reliability of the study was done after the pilot study. Reliability of the tool was assessed by collecting data from 6 infertile couple.

\section{PLAN FOR DATA ANALYSIS \\ Descriptive statistics}

1. Frequency and percentage were used to present the demographic data of nursing students.

\section{Inferential statistics}

1. Non- parametric test: Chi-square test was used to find the association between the physical and psychosocial consequences of infertility with selected demographic variables.

The MS word and Excel were used to generate the tables and graphs for presenting the data and results.

This chapter on research methodology has dealt with research approach, research design, variables, settings of the study, population, sample and sample size, sampling technique, criteria for sample selection, development of the tool, description of the tool, description of the module on tips for coping strategies content validity, reliability of the tool, pilot study, data collection procedure and plan for data analysis.

\section{ETHICAL CONSIDERATION}

1. The ethical clearance was obtained from the ethical research committee of DayanandaSagar University, College of Nursing Sciences, Bengaluru.

2. Permission was obtained from the Principal, DayanandaSagar University, College of Nursing Sciences, Bengaluru.

3. Informed written consent was obtained from the nursing students who are willing to participate in the study.

4. Confidentiality and anonymity of the nursing students was guarded.

5. The data were used only for academic purpose and the publications of the research findings will not reveal the identity of the study setting and subjects.

6. Scientific objectivity of the study was maintained with honesty and impartiality. 


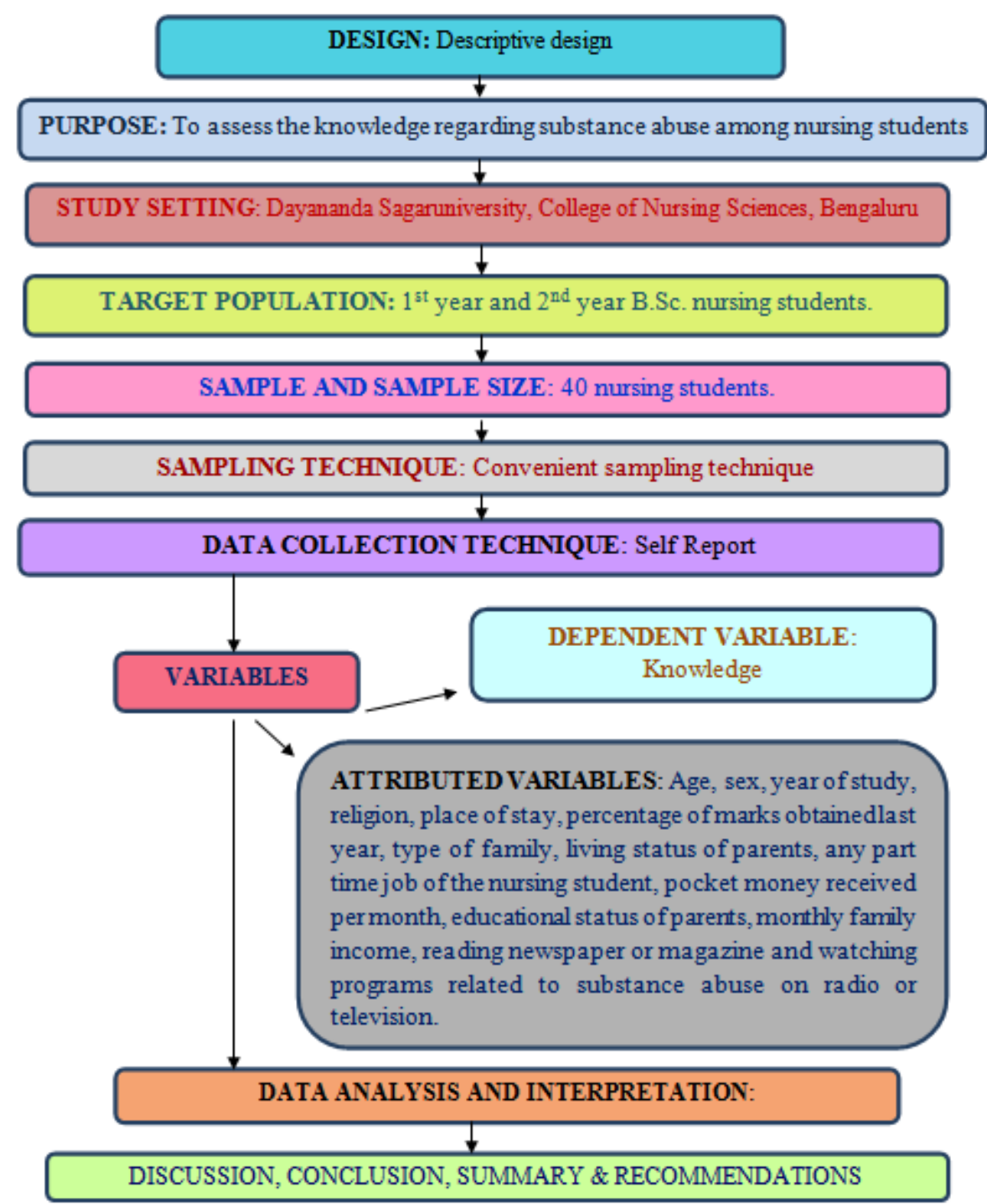

Figure 2: Schematic representation of the research study

\section{RESULTS}

This chapter deals with analysis and interpretation of qualitative data collected from forty students in DayanandaSagar College of Nursing Sciences to assess the knowledge regarding substance abuse.

The data collected regarding level of knowledge regarding Substance Abuse among B.Sc Nursing students of DayanandaSagar College of Nursing, Bangalore were analyzed by using descriptive statistics.

The data were collected using structured questionnaire. The obtained data were analyzed by using descriptive and inferential statistics, which are necessary to assess knowledge regarding substance abuse and to determine the relationship between the selected socio demographic variables and knowledge score.

\section{PRESENTATION OF DATA}

The data is organized and presented under the following broad headings:

\section{Section 1}

Frequency and percentage distribution of demographic variables of study objects.

\section{Section 2}

Assessment of level of knowledge of B.Sc. Nursing students regarding substance abuse

\section{Section 3}

Association of selected demographic variables with level of knowledge regarding substance abuse

Section 1: Frequency and percentage distribution of demographic variables. 
International Journal of Trend in Scientific Research and Development (IJTSRD) ISSN: 2456-6470

Table 1: Distribution of B.Sc. Nursing Students According to Their Demographic Variables

\begin{tabular}{|c|c|c|c|c|}
\hline $\begin{array}{l}\text { Sl. } \\
\text { No. }\end{array}$ & Demographic variables & Category & Frequency & Percentage $(\%)$ \\
\hline \multirow{3}{*}{1.} & \multirow{3}{*}{ Age } & $16-18$ & 4 & 10 \\
\hline & & $19-21$ & 20 & 50 \\
\hline & & $22-24$ & 16 & 40 \\
\hline \multirow[t]{2}{*}{2.} & \multirow{2}{*}{ Gender } & Male & 11 & 27.5 \\
\hline & & Female & 29 & 72.5 \\
\hline \multirow{2}{*}{3.} & \multirow{2}{*}{ Year of study } & First year & 32 & 80 \\
\hline & & Second year & 8 & 20 \\
\hline 4. & Religion & $\begin{array}{l}\text { Hindu } \\
\text { Muslim } \\
\text { Christians } \\
\text { Any other }\end{array}$ & $\begin{array}{l}15 \\
10 \\
9 \\
6\end{array}$ & $\begin{array}{l}37.5 \\
25 \\
22.5 \\
15\end{array}$ \\
\hline 5. & Place of st: & $\begin{array}{l}\text { Home } \\
\text { Hostel } \\
\text { Paying guest } \\
\text { Relative House } \\
\end{array}$ & $\begin{array}{l}10 \\
7 \\
23 \\
0 \\
\end{array}$ & $\begin{array}{l}25 \\
17.5 \\
57.5 \\
0 \\
\end{array}$ \\
\hline \multirow{5}{*}{6.} & \multirow{5}{*}{$\begin{array}{c}\text { Percentage of marks obtain last year } \mathrm{E} \\
\text { DeVe }\end{array}$} & $90 \%$ and above & 0 & 0 \\
\hline & & $80 \%$ and above & 30 & 7.5 \\
\hline & & $70 \%$ and above & $13 \square$ & 32.5 \\
\hline & & $60 \%$ and above & 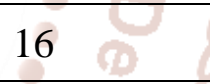 & 40 \\
\hline & & $50 \%$ and above & & 20 \\
\hline \multirow{3}{*}{7.} & \multirow{3}{*}{ Type of family } & Nuclear family & 27 & 67.5 \\
\hline & & Joint family & 9 & 22.5 \\
\hline & & $\begin{array}{l}\text { Single parent } \\
\text { family }\end{array}$ & 4 & 10 \\
\hline \multirow{2}{*}{8.} & \multirow{2}{*}{ Living status of father } & Alive & 38 & 95 \\
\hline & & Dead & 2 & 5 \\
\hline \multirow{2}{*}{9.} & \multirow{2}{*}{ Living status of mother } & Alive & 38 & 9 \\
\hline & & Dead & 2 & 5 \\
\hline \multirow{2}{*}{10.} & \multirow{2}{*}{ Do you have a part time job } & Yes & 2 & 5 \\
\hline & & No & 38 & 95 \\
\hline \multirow{4}{*}{11.} & \multirow{4}{*}{$\begin{array}{l}\text { What is the monthly pocket money you } \\
\text { receive? }\end{array}$} & Below Rs 1000 & 2 & 5 \\
\hline & & Rs 1001-Rs 1500 & 5 & 12.5 \\
\hline & & Rs 1501-Rs 2000 & 8 & 20 \\
\hline & & Rs 2001- Rs 2500 & 9 & 22.5 \\
\hline
\end{tabular}


International Journal of Trend in Scientific Research and Development (IJTSRD) ISSN: 2456-6470

\begin{tabular}{|c|c|c|c|c|}
\hline & & Above 2500 & 16 & 40 \\
\hline \multirow{5}{*}{12.} & \multirow{5}{*}{ Educational status of Father } & $\begin{array}{l}\text { No formal } \\
\text { schooling }\end{array}$ & 1 & 2.5 \\
\hline & & Primary & 1 & 2.5 \\
\hline & & Middle & 2 & 5 \\
\hline & & High school & 20 & 50 \\
\hline & & $\begin{array}{l}\text { College or } \\
\text { University }\end{array}$ & 16 & 40 \\
\hline \multirow{5}{*}{13.} & \multirow{5}{*}{ Educational status of mother } & $\begin{array}{l}\text { No formal } \\
\text { schooling }\end{array}$ & 7 & 17.5 \\
\hline & & Primary & 2 & 5 \\
\hline & & Middle & 4 & 10 \\
\hline & & High school & 14 & 35 \\
\hline & & $\begin{array}{l}\text { College or } \\
\text { University }\end{array}$ & 13 & 32.5 \\
\hline \multirow{4}{*}{14.} & \multirow{4}{*}{$\begin{array}{l}\text { Monthly family income in Rs } \\
3 \\
0\end{array}$} & $\begin{array}{l}\text { Above Rs3000- } \\
\text { Rs } 5000\end{array}$ & 8 & 20 \\
\hline & & Rs 5001-Rs 7000 & 30 & 7.5 \\
\hline & & Rs 7001-Rs9000 & 10 & 25 \\
\hline & & Above Rs9000 & 19 & 47.5 \\
\hline \multirow{4}{*}{15 . } & \multirow{4}{*}{$\begin{array}{l}\text { How often do you read literature } \\
\text { related to drug abuse in newspaper or } \\
\text { magazines? }\end{array}$} & Very often ol & $6 \bigcirc$ & 15 \\
\hline & & Sometimes t: & $16 \circlearrowleft$ & 40 \\
\hline & & Rarely & $9-$ & 22.5 \\
\hline & & Never $4 / 0$ & 90 & 22.5 \\
\hline \multirow{4}{*}{16.} & \multirow{4}{*}{$\begin{array}{l}\text { How often do you listen or watch } \\
\text { programmes related to drugs on } \\
\text { television or radio? }\end{array}$} & Very often & 7 & 17.5 \\
\hline & & Sometimes & 4 & 10 \\
\hline & & Rarely & 16 & 40 \\
\hline & & Never & 12 & 30 \\
\hline
\end{tabular}

\section{Table 1 shows that:}

$>$ Out of 40 samples, 4 subjects $(10 \%)$ were from age group 16-18years, 20 subjects $(50 \%)$ were from age group 19-21 years and 16 subjects $(40 \%)$ were from age group 21-24 years.

$>$ Out of 40 samples, 11 subjects $(27.5 \%)$ were male and 29 subjects $(72.5 \%)$ were female

$>$ Out of 40 samples, 32 subjects $(80 \%)$ were first year students and 8subjects (20\%) were second year students.

$>$ Out of 40 samples, 15 subjects $(37.5 \%)$ were Hindu, 10subjects (25\%) were Muslim, 9subjects
(22.5\%) were Christians and 6 subjects (15\%) were other religion.

Out of 40 samples, 10 subjects (25\%) were staying in their own home, 7 subjects (17.5\%) were staying in hostel and 2 subjects 3(57.5\%) were staying in paying guest.

Out of 40 samples, 3subjects (7.5\%) had scored above $80 \%, 13$ subjects $(32.5 \%)$ had scored above $70 \%, 16$ subjects $(40 \%)$ had scored above $60 \%$ and 8subjects (20\%) had scored above 50\%.Out of 40 samples, $27(67.5 \%)$ were from nuclear family, 
$9(22.5 \%)$ were from joint family and $4(10 \%)$ were from single parents.

$>$ Regarding living status of father, 38(95\%) were alive and $2(5 \%)$ were dead.

$>$ Regarding living status ofmother, 38 (95\%) were alive and $2(5 \%)$ were dead.

$>$ Out of 40 samples, 2 subjects $(5 \%)$ had part time job and 38 subjects $(95 \%)$ had no part time job.

$>$ Out of 40 samples, 2 subjects $(5 \%)$ receive monthly pocket money belowRs 1000,5 subjects $(12.5 \%)$ receive monthly pocket money of Rs 1001-Rs 1500, 8 subjects $(20 \%)$ receive monthly pocket money of Rs 1501-Rs.2000 and 9 subjects $(22.5 \%)$ receive monthly pocket money of Rs.2001-Rs.2500 and 16 subjects (40\%) receive pocket money above Rs.2500.

$>$ Regarding the educational status of father, 1 subject $(2.5 \%)$ had no formal schooling, 1 subject $(2.5 \%)$ had studied till primary school, 2 subjects (5\%) had studied till secondary school, 20 subjects (50\%) had studied till high school, 16(40\%) subjects had studied in college.

$>$ Regarding the educational status of mother,7 subjects $(17.5 \%)$ had no formal schooling, 2 subjects $(5 \%)$ had studied till primary school, 4 subjects(10\%) had studied till secondary school, 14 subjects $(35 \%)$ had studied till high school, 13 subjects $(32.5 \%)$ had studied in college.

$>$ Out of 40 samples, 8 subjects $(20 \%)$ had family income above Rs. 3000-Rs.5000,3 subjects(7.5\%) had family income above Rs.5001-Rs.7000, 10 subjects $(25 \%)$ had family income above Rs.7001Rs.9000, 19 subjects had family income above Rs.9001.

Out of 40 samples, 6 subjects $(15 \%)$ veryoften read the literature related to drug abuse in newspaper/magazine, 16 subjects (40\%) sometimes read the literature related to drug abuse in newspaper,9 subjects (22.55) rarely read the literature related to drug abuse, 9 subjects $(22.5 \%)$ never read the literature related to drug abuse.

Out of 40 samples, 7 subjects(20\%)very often watch programme related to drug on radio or television, 16 subjects $(40 \%)$ rarely watch or listen programs related to drug abuse, 4 subjects $(10 \%)$ never watch or listen programs related to drug abuse, 12 subjects $(30 \%)$ sometimes watch or listen program related to drug abuse on radio or television.

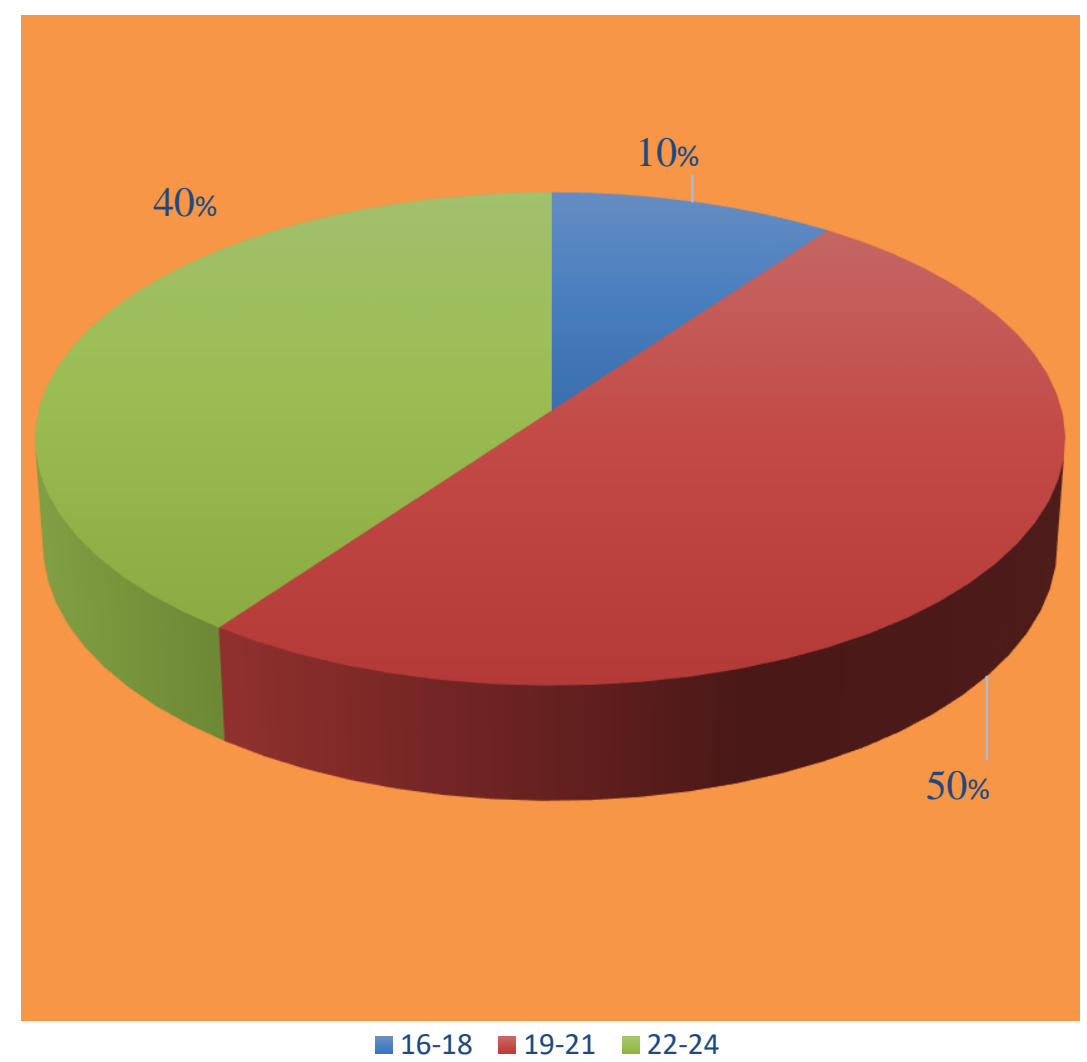

Figure1: Percentage distribution of nursing students according to age

Figure I shows that the maximum number 50\% students belongs to $19-21$ years of age, and $40 \%$ of students belongs to 22-24 years of age, and $10 \%$ of students belongs to 16-18 years of age respectively. 


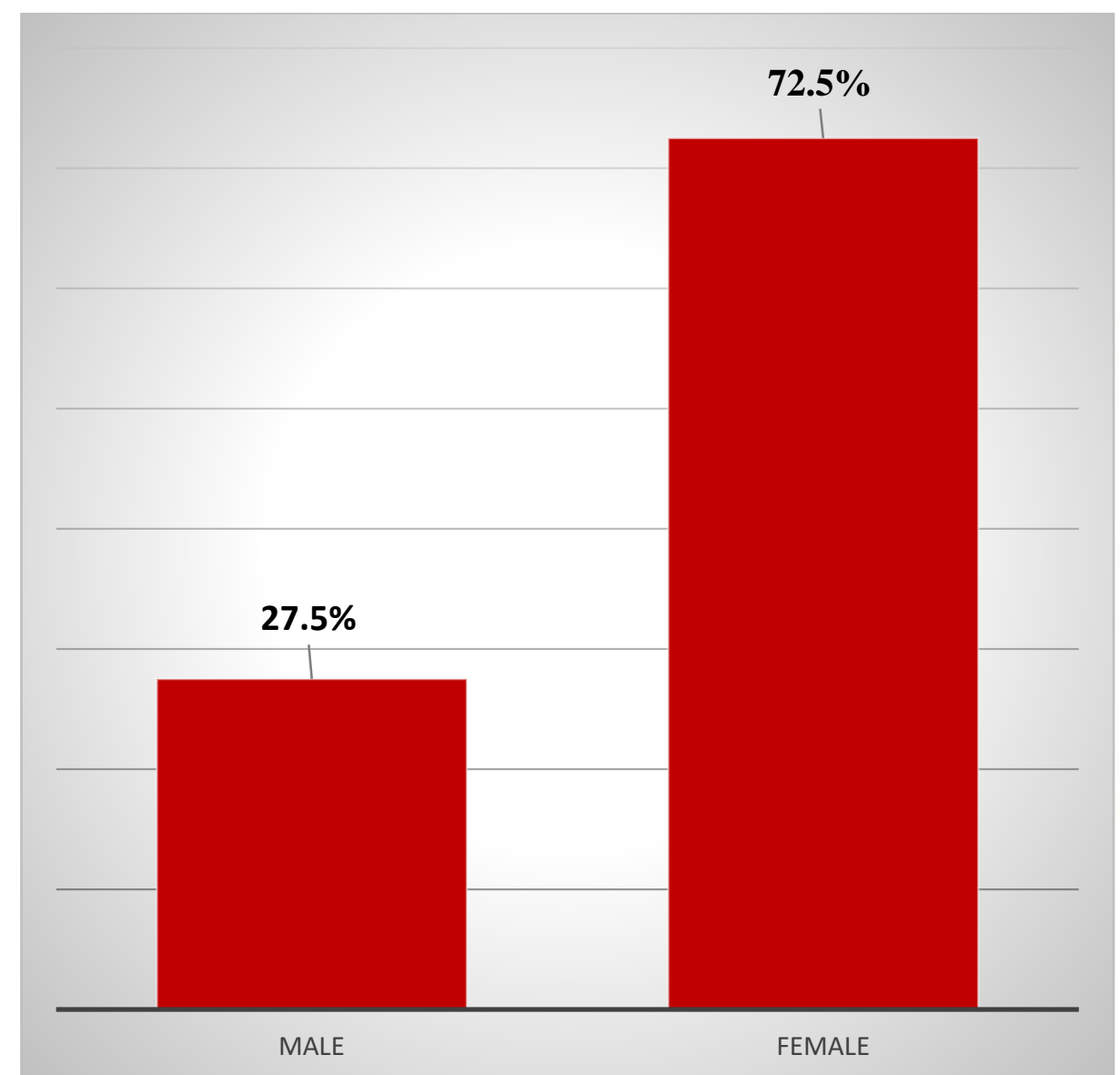

Figure 2: Percentage distribution of nursing students according to sex

Figure II shows that $72.5 \%$ (29) students are female and $27.5 \%$ (11) students are male.

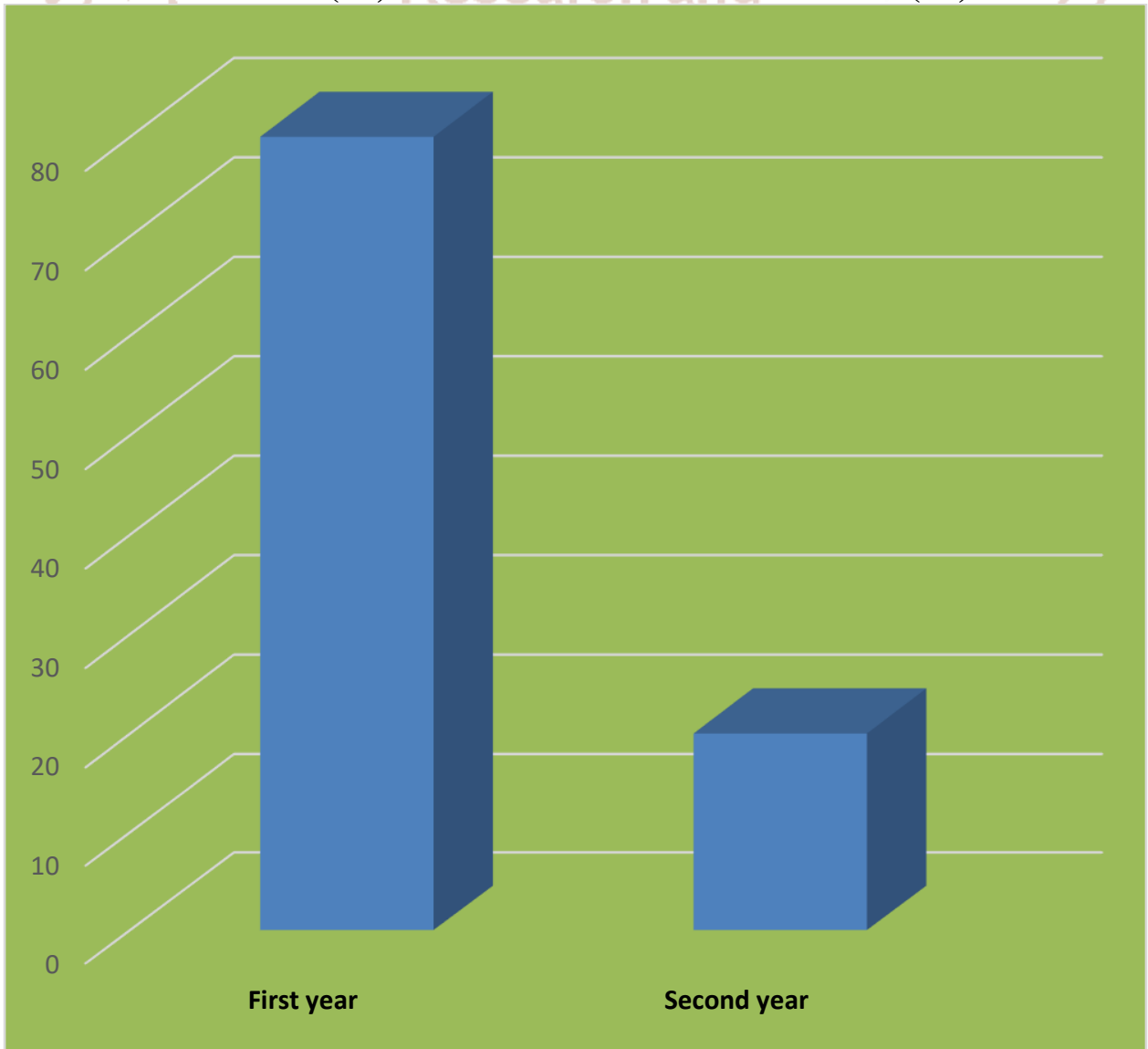

Figure 3: Percentage distribution of nursing students according to year of study 
International Journal of Trend in Scientific Research and Development (IJTSRD) ISSN: 2456-6470

Figure III shows that $80 \%(32)$ students are first year and $20 \%(8)$ students are second year students respectively.

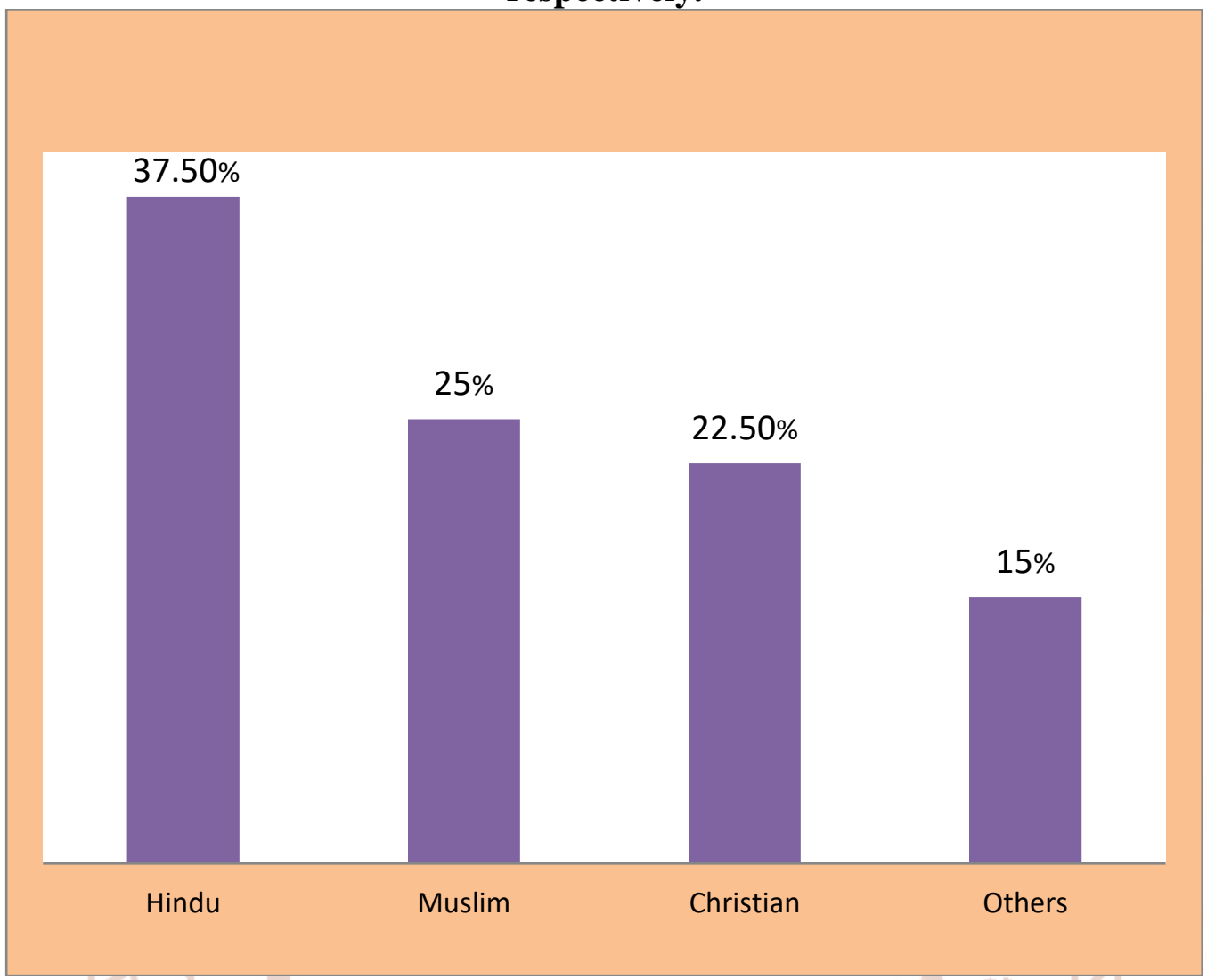

Figure 4: Percentage distribution of nursing students according to religion

Figure IV shows that $37.5 \%$ of the students were Hindu, $22.5 \%$ were Christians, 25\% were Muslims and $15 \%$ were other Religion.

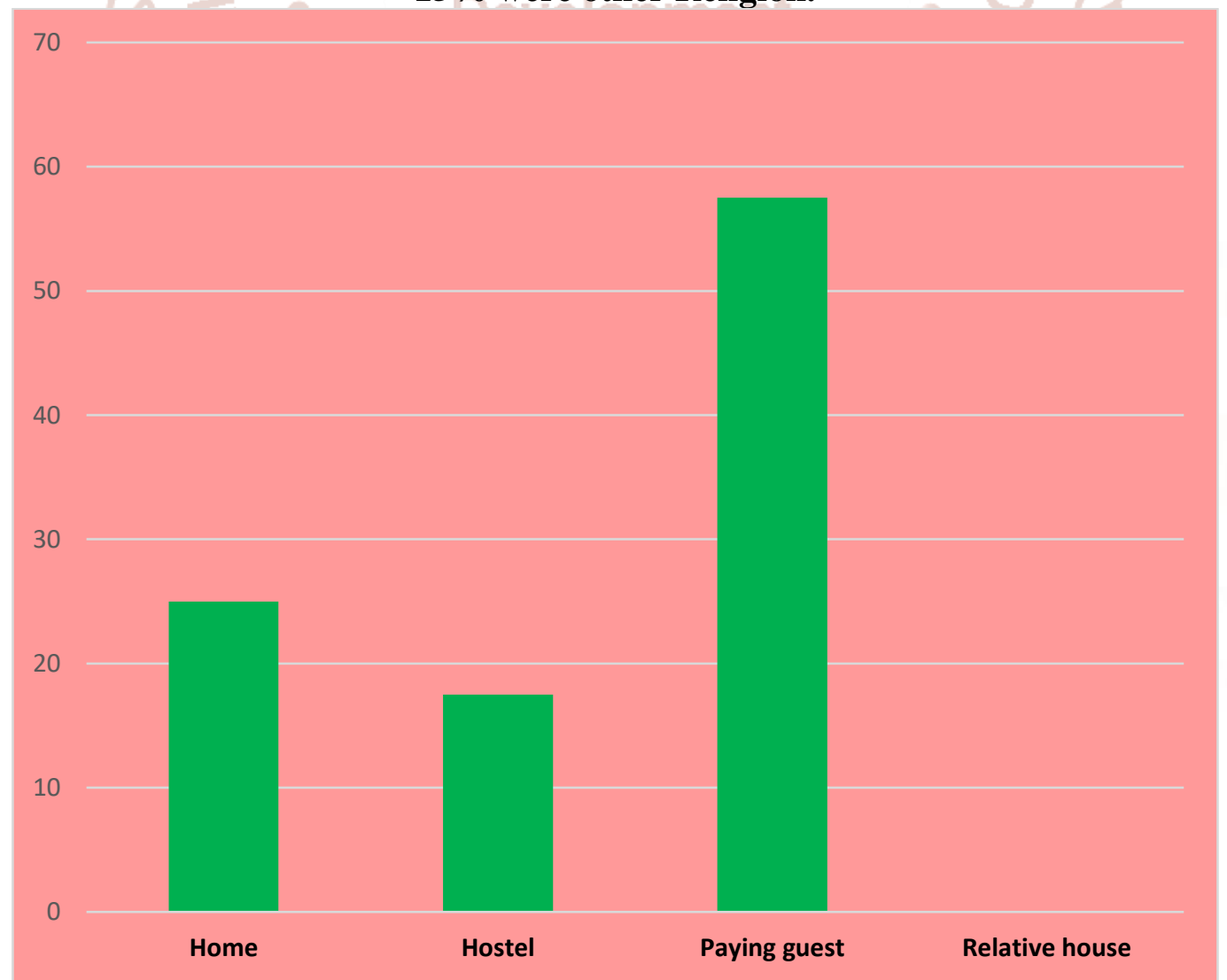

Figure 5: Percentage distribution of nursing students according to place of stay 
Figure V shows that 57.5\% of students are staying at Paying Guest, 255 were staying at Home, 17.5\% were staying at Hostel.

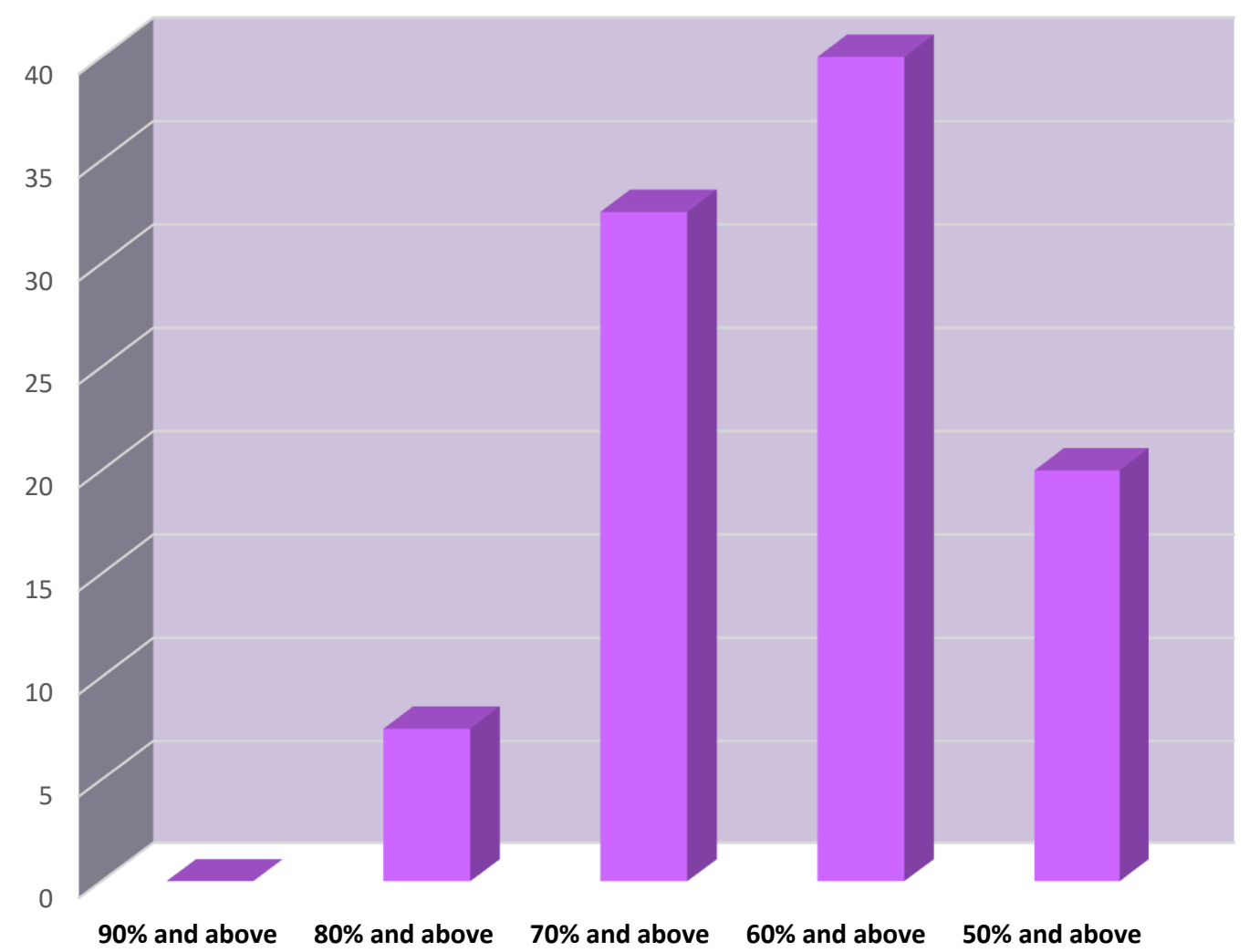

Figure 6: Percentage distribution of nursing students according to marks obtained last year

Figure VI shows that $40 \%$ of the students scored above $60 \%, 32.5 \%$ scored above $70 \%, 20 \%$ scored above $50 \%$ and $7.5 \%$ scored above $80 \%$ respectively.

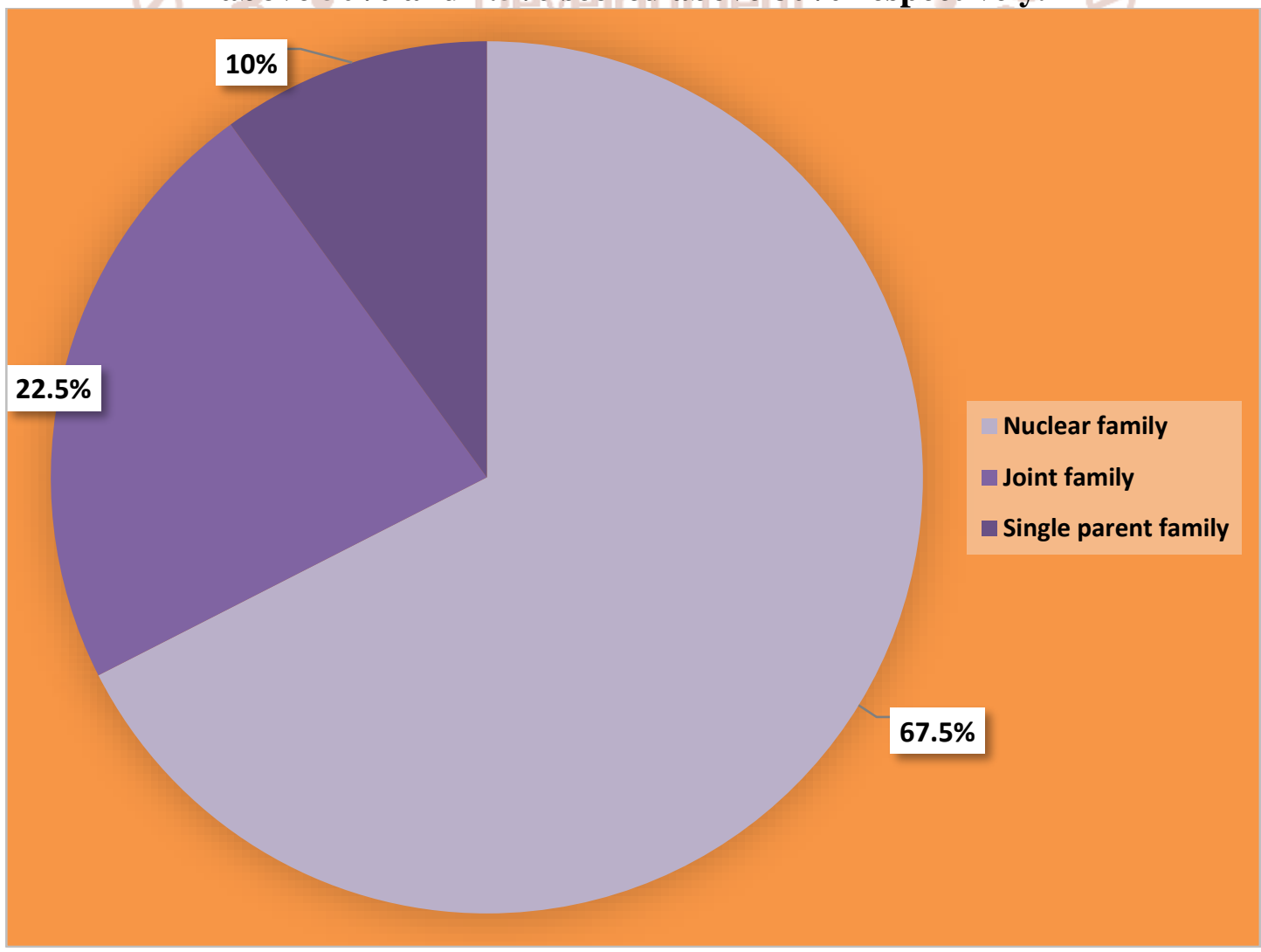

Figure 7: Percentage distribution of nursing students according to type of family 
International Journal of Trend in Scientific Research and Development (IJTSRD) ISSN: 2456-6470

Figure VII shows that $67.5 \%$ of the students belong to Nuclear Family, $22.5 \%$ belongs to Joint Family and $10 \%$ belongs to Single Parents.

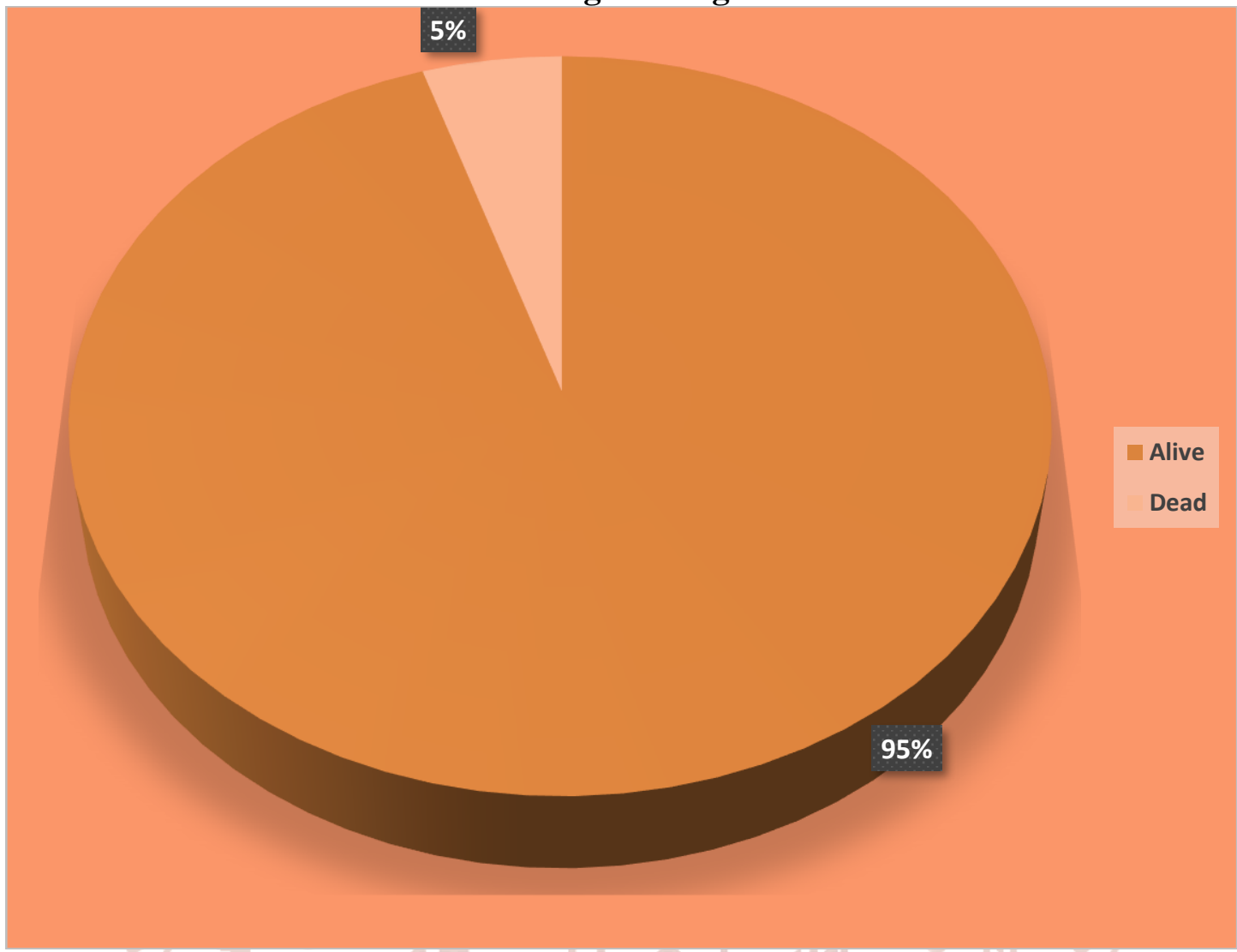

Figure 8: Percentage distribution of nursing students according to living status of father

Figure VIII shows that $95 \%$ of the student's father are alive and $5 \%$ are dead.

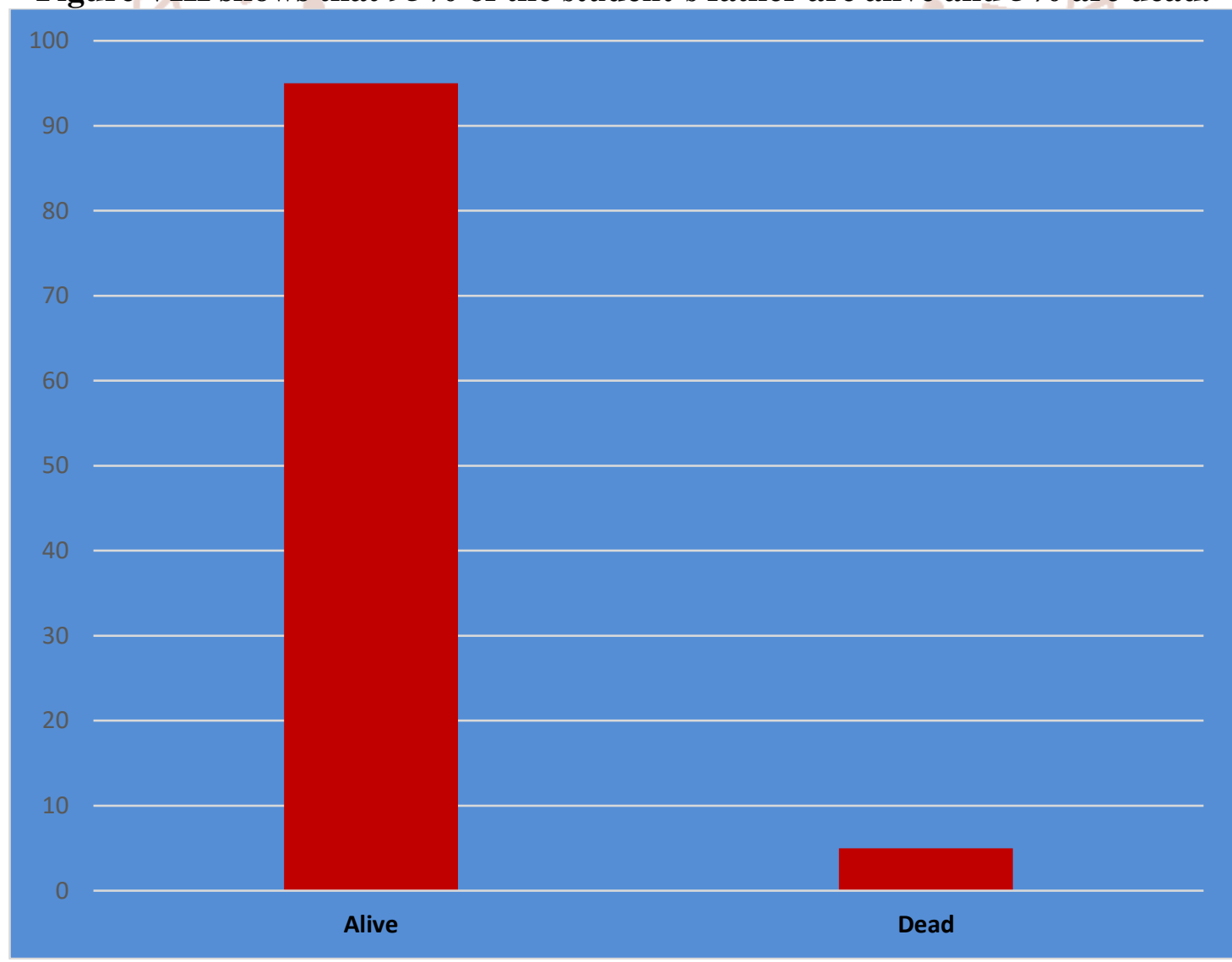

Figure 9: Percentage distribution of nursing students according to living status of mother 
International Journal of Trend in Scientific Research and Development (IJTSRD) ISSN: 2456-6470

Figure IX shows that $95 \%$ of thestudents mother are alive and $5 \%$ of them are dead

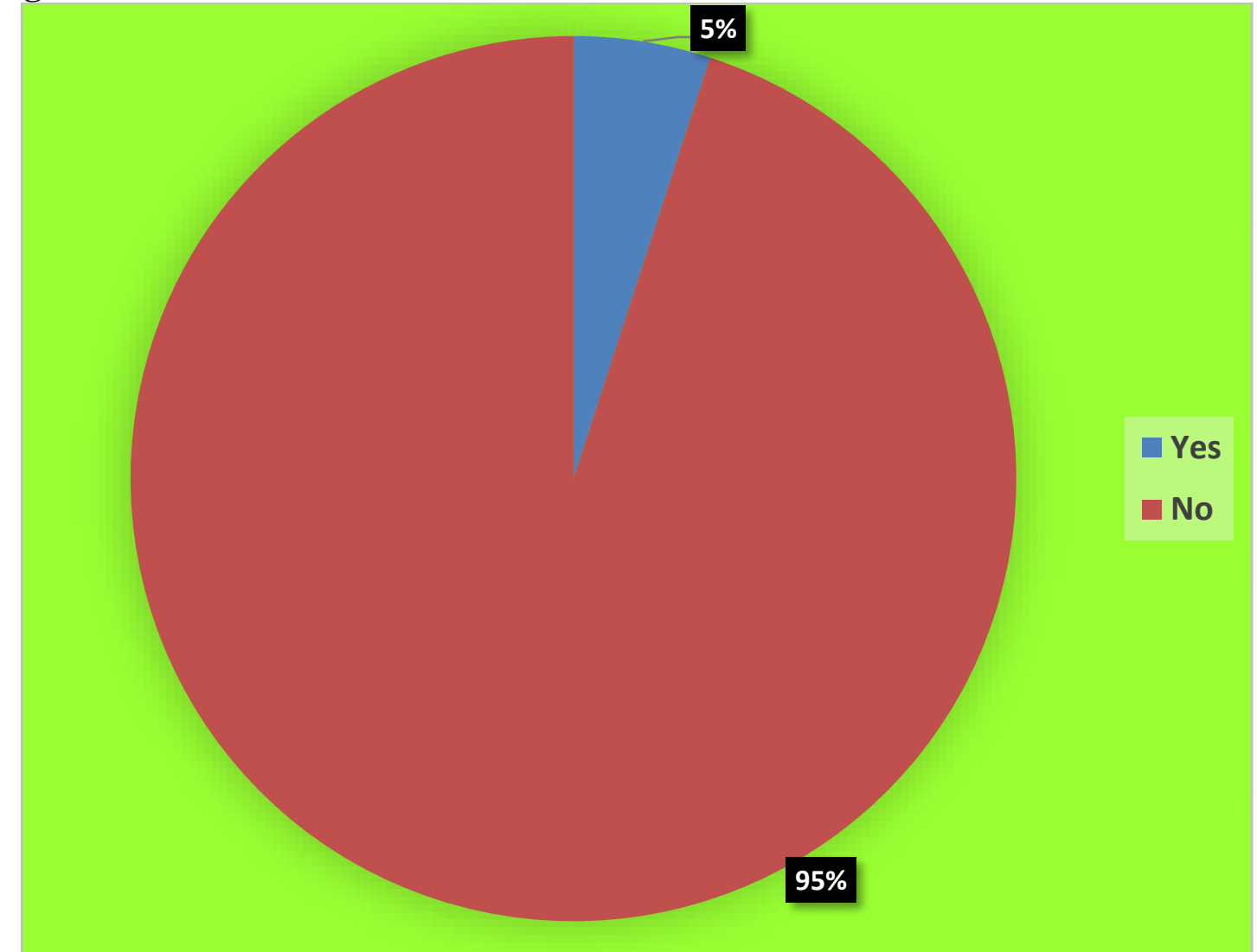

Figure 10: Percentage distribution of nursing students according to part time job

Figure X shows that $95 \%$ of the students don't have part time job and $\mathbf{5 \%}$ have part time job.

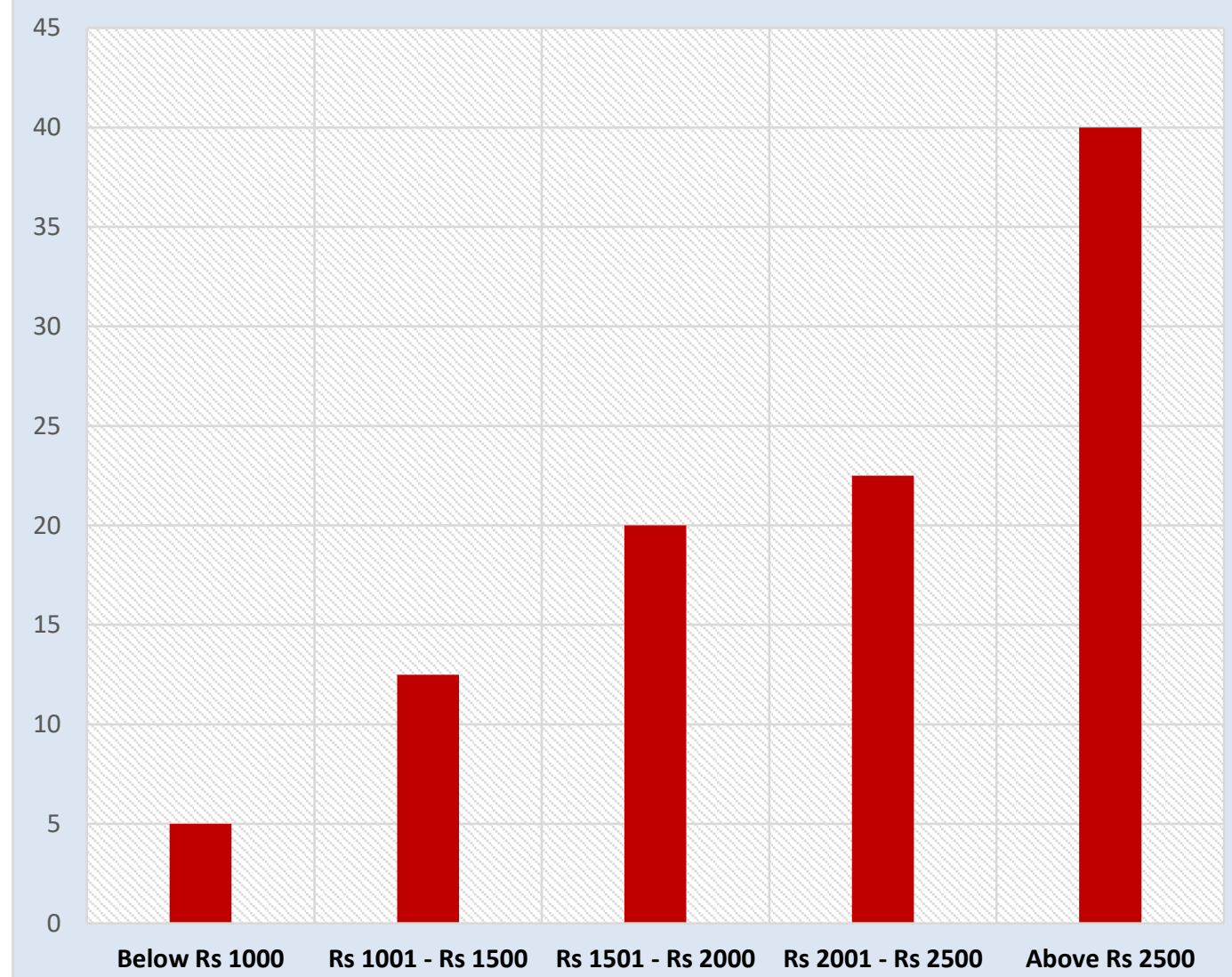

Figure 11: Percentage distribution of nursing students according to the monthly pocket money they receive. 
International Journal of Trend in Scientific Research and Development (IJTSRD) ISSN: 2456-6470

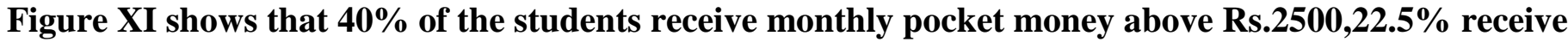
between Rs.2001-2500, $20 \%$ receive between $R s, 1501-2000,5 \%$ receive below Rs.1000.

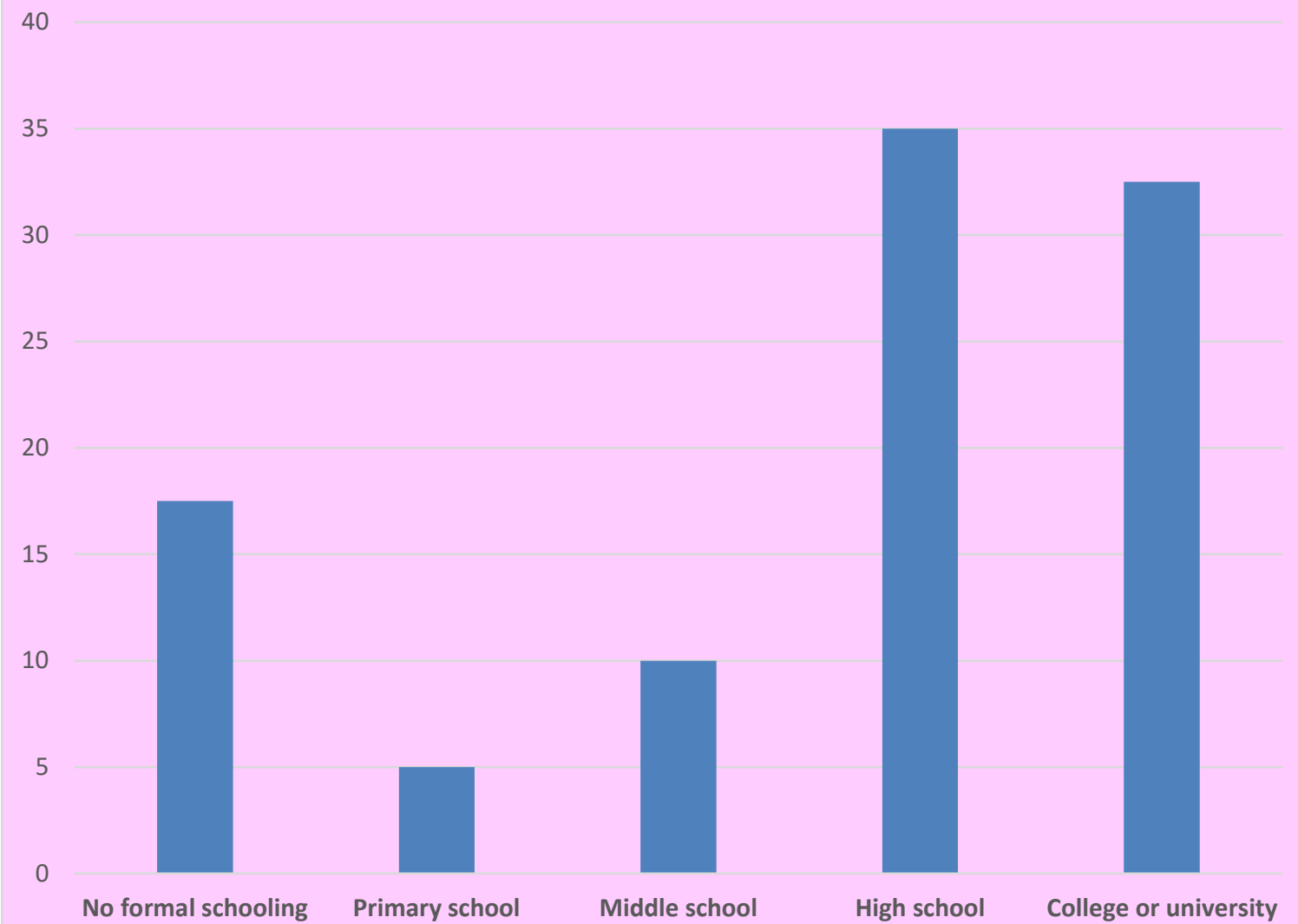

Figure 12: Percentage distribution of nursing students according to educational status of father.

Figure XII shows that $5 \%$ of the students father have secondary level education, $2.5 \%$ have primary level education, $2.5 \%$ have no formal schooling.

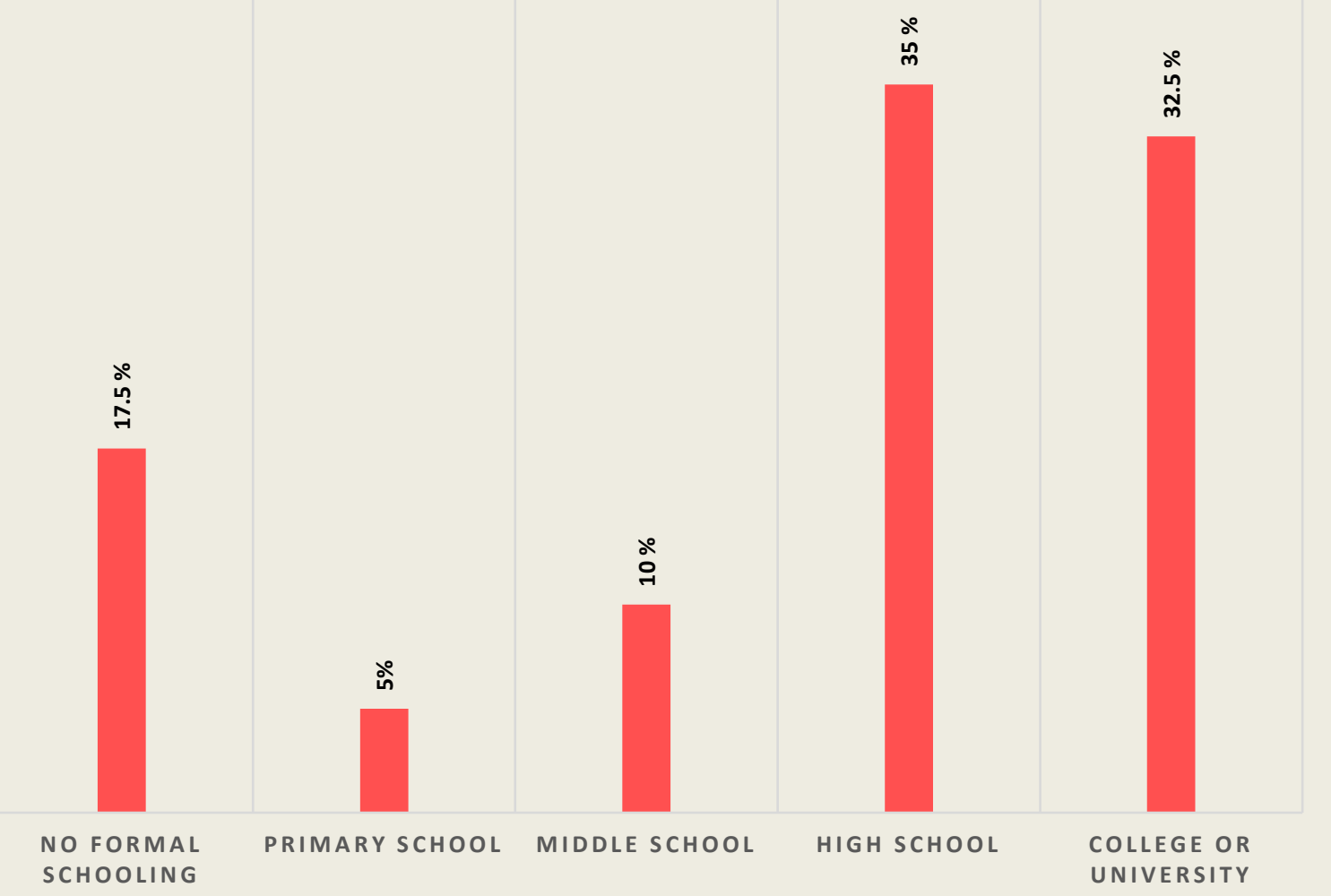

Figure 13: Percentage distribution of nursing students according to educational status of mother. 
International Journal of Trend in Scientific Research and Development (IJTSRD) ISSN: 2456-6470

Figure XIII shows that $35 \%$ of the students mother have studied till high school, $32.5 \%$ have studied till college, $\mathbf{1 7 . 5 \%}$ have no formal schooling, $10 \%$ have studied till secondary level, $5 \%$ have studied till primary level

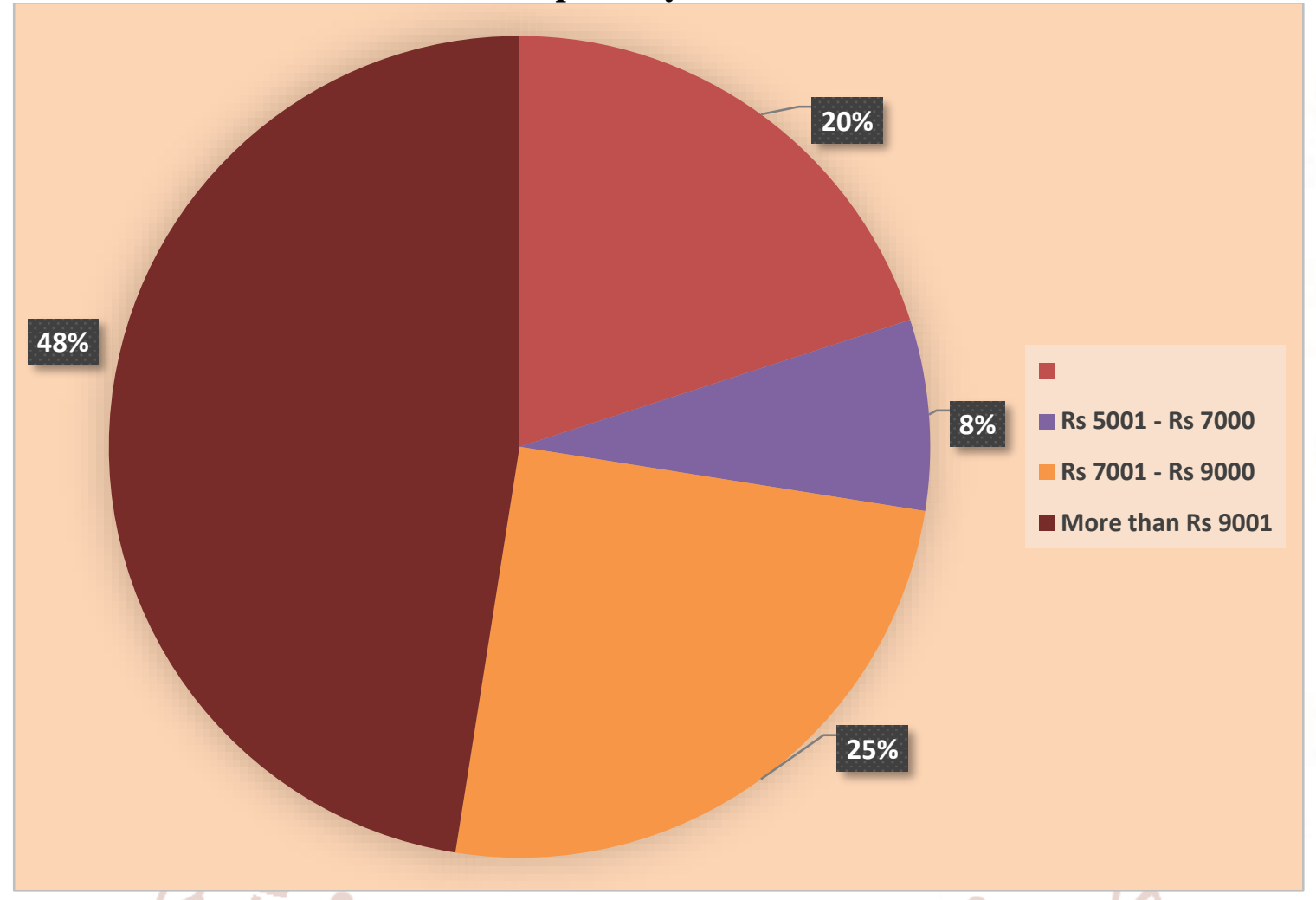

Figure 14: Percentage distribution of nursing students according to monthly family income

Figure XIV shows that $47.5 \%$ of the students have family income above Rs.9000, $25 \%$ have family income between Rs.7001-Rs.9000, $20 \%$ have family income between Rs.3000-Rs.5000, 7.5\% have family income between Rs.5001-Rs.7000.

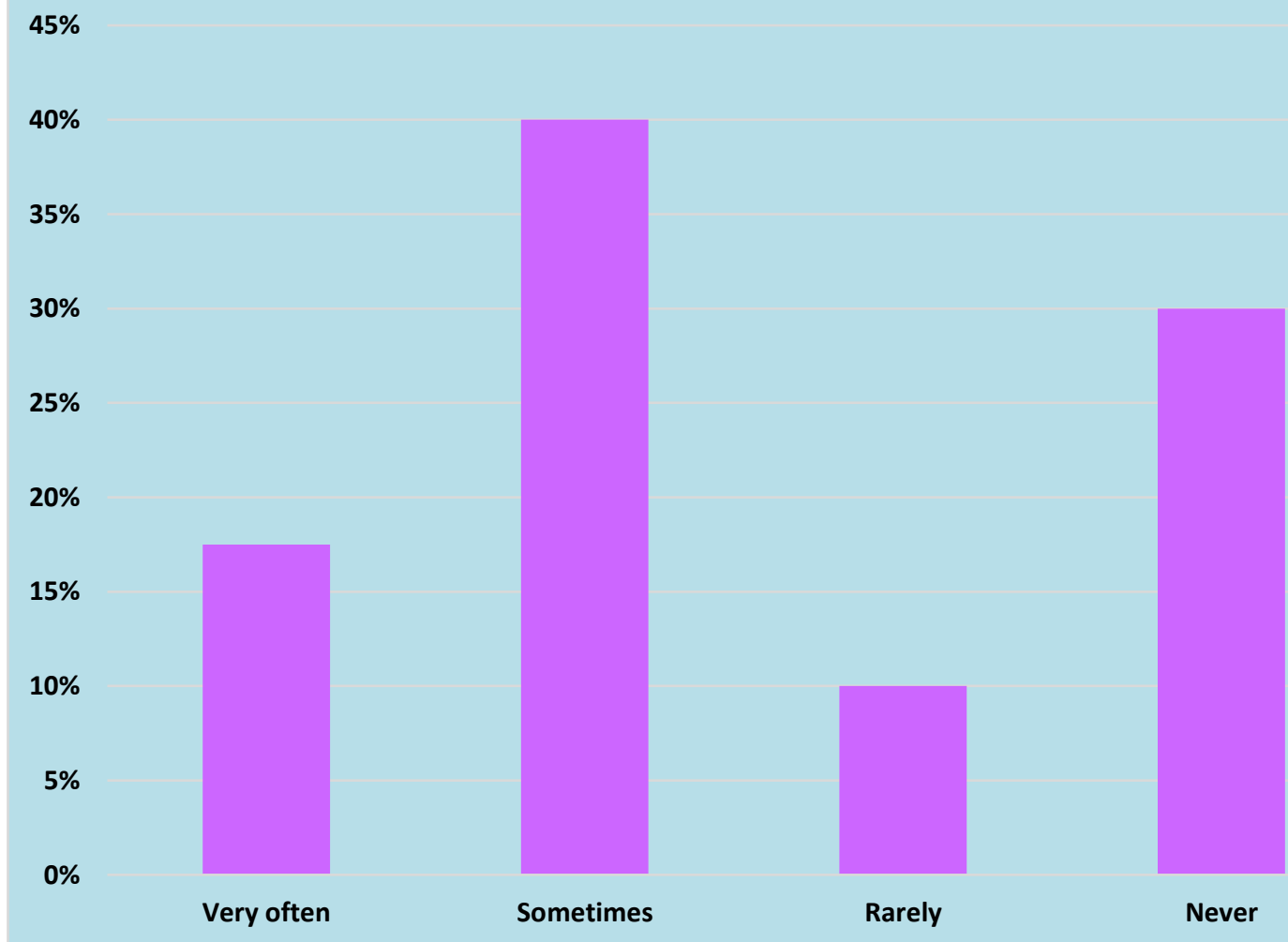

Figure 15: Percentage distribution of nursing students according to reading of newspaper or magazines regarding drug abuse 
Figure XV shows that $\mathbf{4 0 \%}$ of the students sometimes read newspaper or magazines regarding drug Abuse, 22.5\% of them read rarely, 22.5\% never read, $15 \%$ read very often.

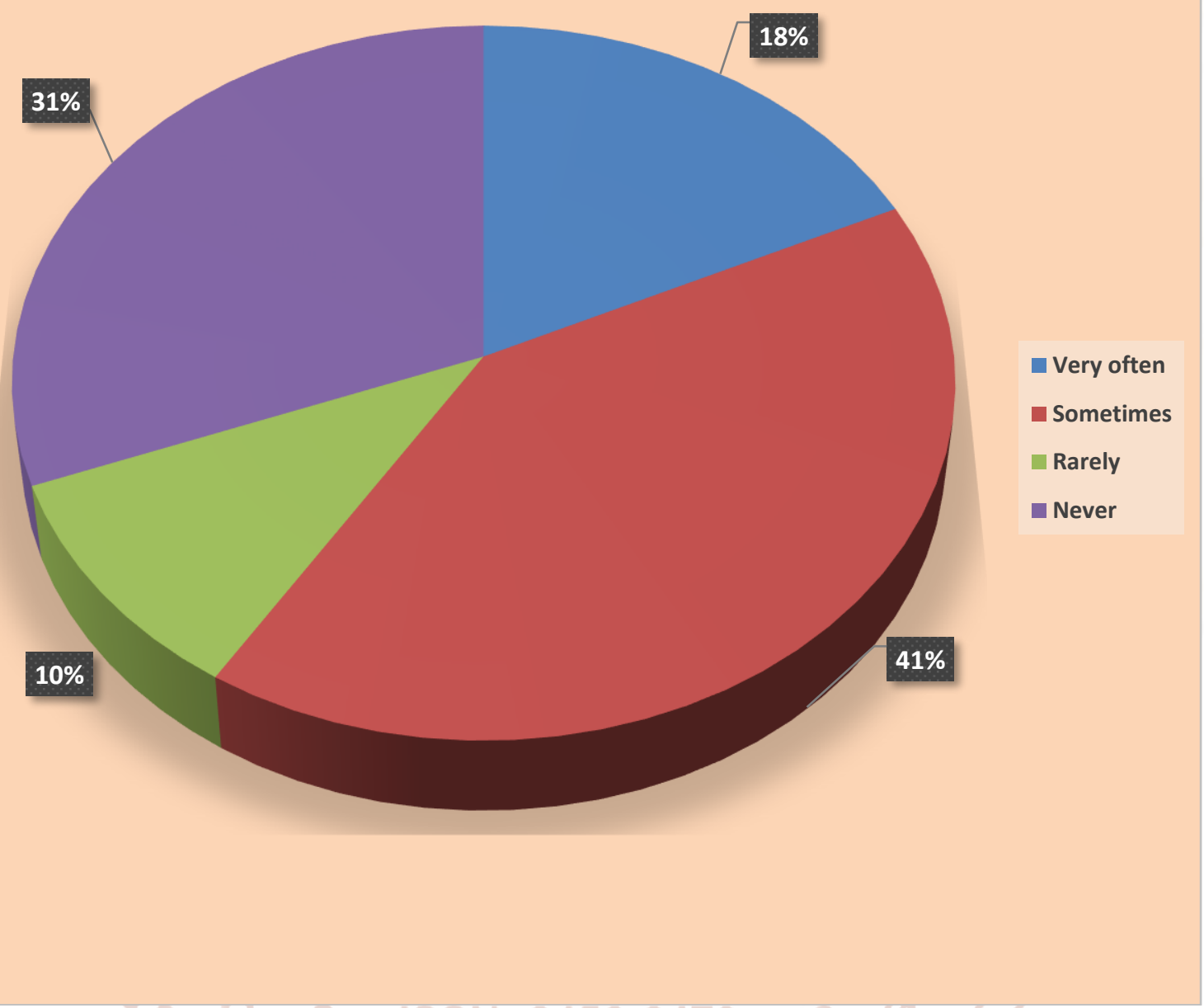

Figure 16: Percentage of distribution of nursing students according to listening to radio or watching television regarding drug abuse

Figure XVI shows that $17.5 \%$ of the students very often listen or watch the programmes, $\mathbf{1 0} \%$ of them watch sometimes, $40 \%$ of them rarely watch and $30 \%$ of them never watch or listen programmes related to substance abuse.

Section 2: Assessment of level of knowledge of B.Sc. Nursing students regarding substance abuse.

Table 2: Distribution of B.Sc. Nursing Students According to Level of Knowledge Regarding Substance Abuse

\begin{tabular}{|c|c|c|c|}
\hline $\begin{array}{c}\text { Sl. } \\
\text { No. }\end{array}$ & $\begin{array}{c}\text { Level of } \\
\text { knowledge }\end{array}$ & Frequency & $\begin{array}{c}\text { Percentage } \\
(\%)\end{array}$ \\
\hline 1 & Inadequate & 21 & 52.5 \\
\hline 2 & Moderate & 19 & 47.5 \\
\hline 3 & Adequate & 0 & 0 \\
\hline
\end{tabular}

Table 2 revealed that 21 of the B.Sc. nursing students $(52.5 \%)$ had inadequate knowledge, $19(47.5 \%)$ had moderate knowledge whereas, none had score adequate knowledge. 


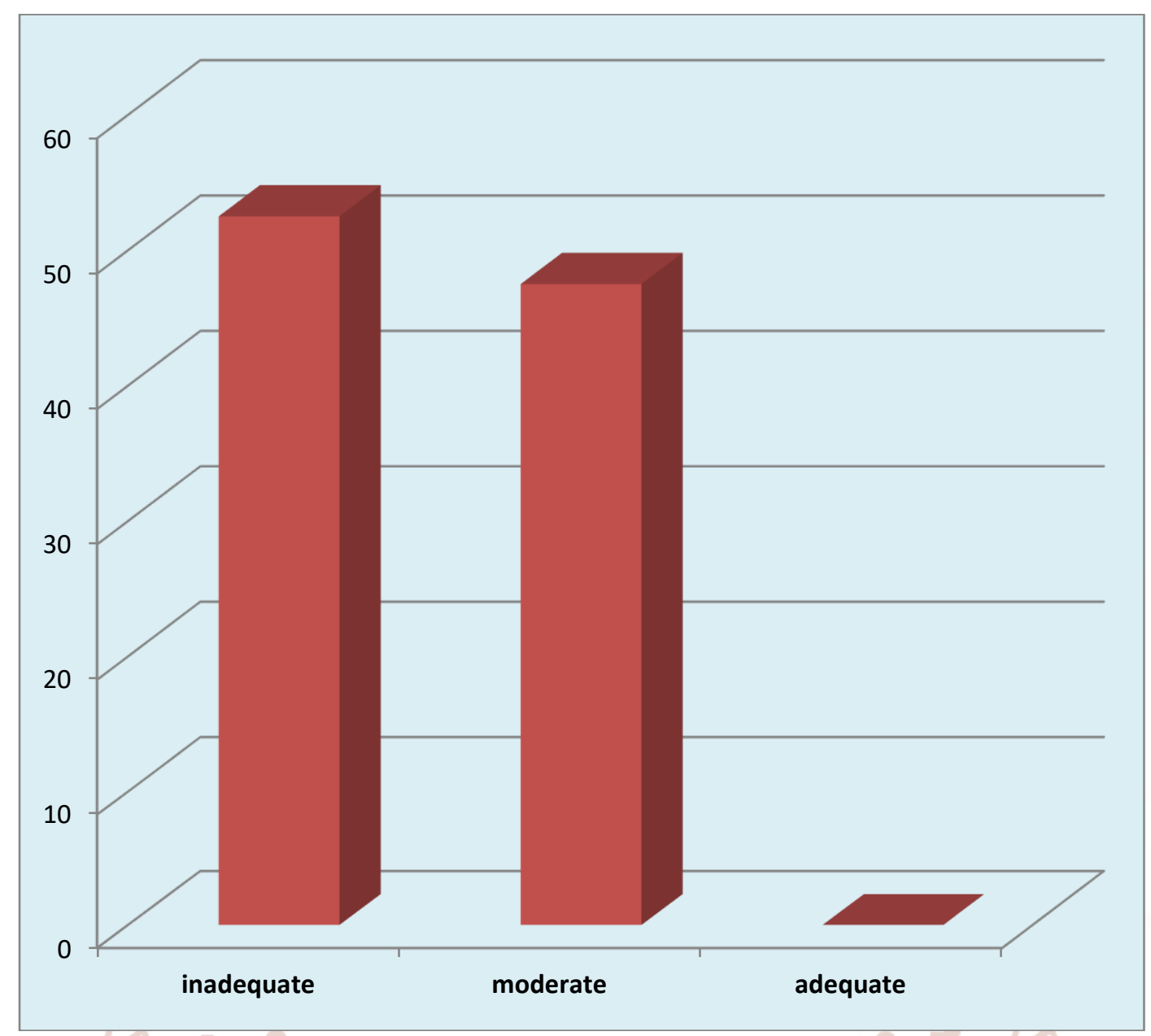

Figure 17: Distribution of B.Sc. nursing students according to level of knowledge

Figure XVII shows that $52.5 \%$ of the students have inadequate level of knowledge, $47.5 \%$ had moderate knowledge whereas none had scored adequate knowledge.

Section 3: Association of selected demographic variables with level of knowledge regarding substance abuse.

Table 3: Association between Level of Knowledge of B.Sc. Nursing Students and Their Selected Demographic Variables

\begin{tabular}{|c|c|c|c|c|c|c|c|c|c|}
\hline \multirow{2}{*}{\multicolumn{2}{|c|}{$\begin{array}{l}\text { SI. } \\
\text { no. }\end{array}$}} & \multirow{2}{*}{$\begin{array}{l}\text { Demographic } \\
\text { variables }\end{array}$} & \multirow{2}{*}{ Categories } & \multicolumn{3}{|c|}{ Knowledge } & \multirow{2}{*}{$\begin{array}{c}x^{2} \\
\text { Value }\end{array}$} & \multirow{2}{*}{ df } & \multirow{2}{*}{ Significance } \\
\hline & & & & Inadequate & Moderate & Adequate & & & \\
\hline \multirow{3}{*}{\multicolumn{2}{|c|}{1.}} & \multirow{3}{*}{ Age } & $16-18$ & 2 & - & & \multirow{3}{*}{2.079} & \multirow{3}{*}{2} & \multirow{3}{*}{$\begin{array}{l}\mathrm{P}>0.05 \\
\text { NS }\end{array}$} \\
\hline & & & $19-21$ & 13 & 10 & & & & \\
\hline & & & $22-24$ & 7 & 8 & & & & \\
\hline \multirow{2}{*}{\multicolumn{2}{|c|}{2.}} & \multirow{2}{*}{ Gender } & Male & 7 & 5 & & \multirow{2}{*}{0.077} & \multirow{2}{*}{1} & \multirow{2}{*}{$\begin{array}{l}\mathrm{P}<0.005 \\
\mathrm{~S}\end{array}$} \\
\hline & & & Female & 15 & 13 & & & & \\
\hline \multirow{2}{*}{\multicolumn{2}{|c|}{ 3. $\mathrm{Y}$}} & \multirow[b]{2}{*}{ Year of study } & First year & 20 & 11 & & \multirow[b]{2}{*}{5.041} & \multirow[b]{2}{*}{1} & \multirow{2}{*}{$\begin{array}{l}\mathrm{P}>0.005 \\
\text { NS }\end{array}$} \\
\hline & & & $\begin{array}{l}\text { Second } \\
\text { year }\end{array}$ & 2 & 7 & & & & \\
\hline \multirow{4}{*}{\multicolumn{2}{|c|}{4.}} & \multirow{4}{*}{ Religion } & Hindu & 10 & 4 & & \multirow{4}{*}{7.9} & \multirow{4}{*}{3} & \multirow{4}{*}{$\begin{array}{l}\mathrm{P}>0.005 \\
\text { NS }\end{array}$} \\
\hline & & & Muslim & 8 & 2 & & & & \\
\hline & & & Christians & 3 & 7 & & & & \\
\hline & & & Any other & 2 & 4 & & & & \\
\hline \multirow{2}{*}{5.} & \multirow{2}{*}{$\mathrm{P}$} & \multirow{2}{*}{ Place of stay } & Home & 8 & 3 & & \multirow{2}{*}{5.018} & \multirow{2}{*}{3} & \multirow{2}{*}{$\begin{array}{l}\mathrm{P}>0.05 \\
\text { NS }\end{array}$} \\
\hline & & & Hostel & 2 & 4 & & & & \\
\hline
\end{tabular}


International Journal of Trend in Scientific Research and Development (IJTSRD) ISSN: 2456-6470

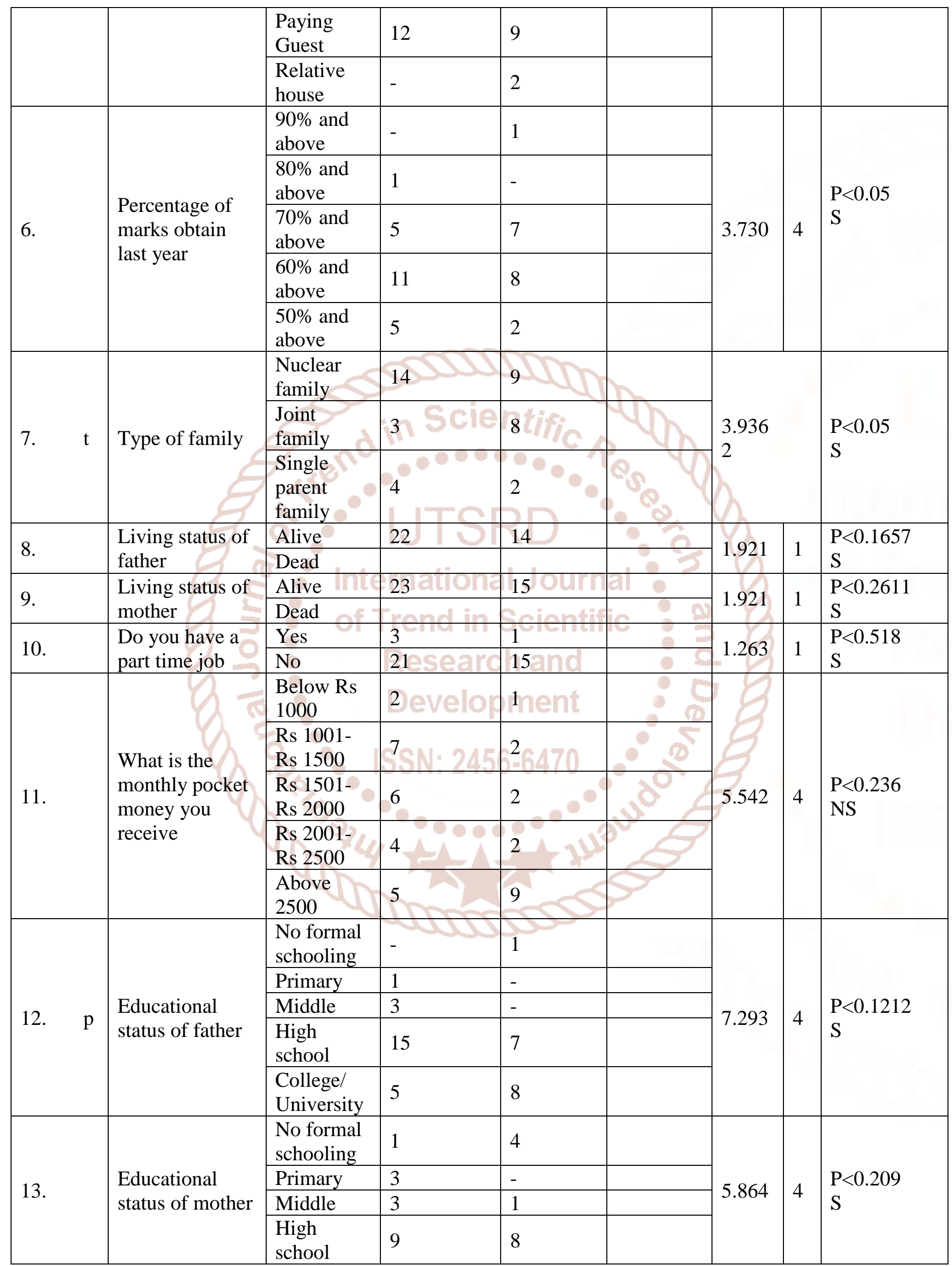


International Journal of Trend in Scientific Research and Development (IJTSRD) ISSN: 2456-6470

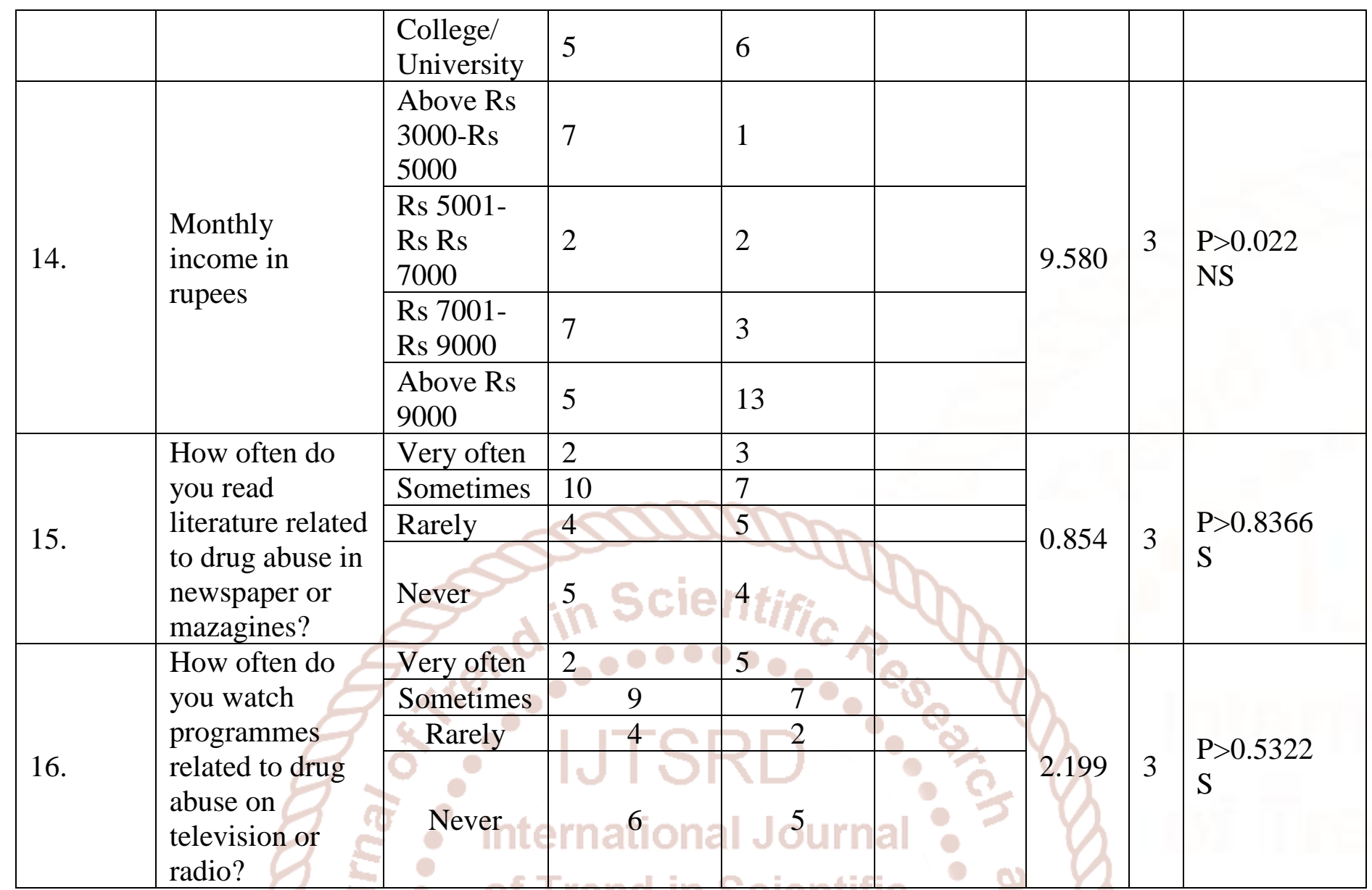

Note: S-denotes significant at 0.05 level $(\mathrm{p}<0.05)$, NS-Not significant at 0.05 level $(\mathrm{p}>0.05)$.

Analyzed data in Table no. 3 revealed that there was a significant association between $\%$ of marks, type of family, place of stay, part time job, educational status of the parents, frequency of reading literature related to drug abus, frequency of watching programme on television or radio.

There was no significant association found between in view of inadequate statistically significant to reject the hypothesis.

Hypothesis H1 is accepted.

\section{MAJOR FINDINGS OF THE STUDY}

$>$ Majority of the subjects were 16 years old $(56.7 \%)$ and minority of the subjects were 18 years old $(10 \%)$ in experimental group whereas majority of the subjects were17 years old(63.3\%) and minority of the subjects were 18 years old(10\%) in control group.

$>$ Majority of the subjects were Hindu (90\%) and minority of the subjects were Muslim(10\%) in experimental group whereas majority of the subjects were Hindu (80\%) and minority of the subjects were Muslim (20\%) in control group.
Majority of the subjects lived in urban areas $(86.7 \%)$ and minority of the subjects lived in rural $\operatorname{areas}(13.3 \%)$ in experimental group whereas majority of the subjects lived in urban $\operatorname{areas}(96.7 \%)$ and minority of the subjects lived in rural areas $(3.3 \%)$ in control group.

Majority of the subjects lived in nuclear family(93.3\%) and minority of the subjects lived in joint family(6.7\%) in experimental group whereas majority of the subjects lived in nuclear family $(70.0 \%)$ and minority of the subjects lived in extended family(13.3\%) in control group.

Majority of the subjects mothers' were in the age group of 36-40 years (56.7\%) and minority of the subjects mothers' were in the age group of 4152 years $(20.0 \%)$ in experimental group whereas majority of the subjects mothers' were in the age group of 36-40 years (40.0\%) and minority of the subjects mothers' were in the age group of 41-52 years as well as 31-35years (30.0\%) in control group.

Majority of the subjects fathers' had secondary education as well as degree and post-graduation $(20.0 \%)$ and minority of the subjects fathers' had PUC education (6.7\%) in experimental group 
whereas majority of the subjects fathers' had high school education $(30.0 \%)$ and minority of the subjects fathers' were post graduate $(3.3 \%)$ in control group.

$>$ Majority of the subjects mothers' were home makers $(60.0 \%)$ and minority of the subjects mothers' were business women and self-employed workers $(6.7 \%)$ in experimental group whereas majority of the subjects mothers' were home makers $(66.7 \%)$ and minority of the subjects mothers' were business women $(3.3 \%)$ in control group.

$>$ Majority of the subjects fathers were business men $(40.0 \%)$ and minority of the subjects fathers were private workers $(6.7 \%)$ in experimental group whereas majority of the subjects fathers were business men $(33.3 \%)$ and minority of the subjects fathers were government employers $(10 \%)$ in control group.

$>$ Majority of the subjects parents monthly income were between Rs. 25000- 5000 (46.7\%) and minority of the parents monthly income was more than Rs 50000 (20.0\%) in experimental group whereas majority of the subjects parents monthly income were between Rs. 25000- 5000 (46.7\%) and minority of the subjects parents monthly income was less than Rs 25000 as well as more than Rs 50000 in control group.

$>$ Majority of the subjects had mixed diet (56.7\%) and minority of the subjects had vegetarian $(10.0 \%)$ in experimental group whereas majority of the subjects had mixed diet as well as nonvegetarian $(43.3 \%)$ and minority of the subjects had vegetarian $(13.4 \%)$ in control group.

$>$ Majority of the subjects were interested in other activities $(66.7 \%)$ and minority of the subjects interested in dance activities (36.7\%) in experimental group whereas majority of the subjects were interested in other activities (46.7\%) and minority of the subjects interested in dance activities $(36.7 \%)$ in control group.

$>$ Majority of the subjects had family history of dysmenorrhea $(56.7 \%)$ and minority of the subjects had no as well as no response for family history of dysmenorrhea (43.3\%) in experimental group whereas majority of the subjects had no as well as no response for family history of dysmenorrhea $(80.0 \%)$ and minority of the subjects had family history of dysmenorrhea $(56.7 \%)$ in control group.

$>$ Majority of the subjects had mother as well as no response for relationship of family member with history of dysmenorrhea (43.3\%) and minority of the subjects had sisters for relationship of family member with history of dysmenorrhea (13.3\%) in experimental group whereas majority of the subjects had no response for relationship of family member with history of dysmenorrhea (80.0\%) and minority of the subjects had sisters for relationship of family member with history of dysmenorrhea $(3.3 \%)$ in control group.

Majority of the subjects attained age at menarche from the age group of (13-15) years of age $(56.7 \%)$ and minority of the subjects attained age at menarche from the age group of (11-12) years of age $(43.3 \%)$ in experimental group whereas majority of the subjects attained age at menarche from the age group of (13-15) years of age $(70.0 \%)$ and minority of the subjects attained age at menarche from the age group of (11-12) years of age $(30.0 \%)$ in control group.

Majority of the subjects had menstrual cycles between $28-10$ days $(60.0 \%)$ and minority of the subjects had less than 28 days $(16.7 \%)$ in experimental group whereas majority of the subjects had menstrual cycles between 28-10 days $(56.7 \%)$ and minority of the subjects had less than 28 days $(13.3 \%)$ in control group.

Majority of the subjects had menstrual flow between 3-5 days $(66.7 \%)$ and minority of the subjects had less than 3 days (3.3\%) in experimental group whereas majority of the subjects had menstrual flow between 3-5days $(73.3 \%)$ and minority of the subjects had less than 3 days as well as 6-7 days (13.3\%) in control group.

Majority of the subjects had menstrual bleeding moderate $(80 \%)$ and minority of the subjects had mild $(6.7 \%)$ in experimental group whereas majority of the subjects had menstrual bleeding moderate ( $70 \%)$ and minority of the subjects had sever menstrual bleeding $(3.3 \%)$ in control group.

Majority of the subjects had regular menstrual cycle in experimental group as well as in control group (100.0\%).

Majority of the subjects had duration of pain assessment rare $(53.3 \%)$ and minority of the subjects had daily $(6.7 \%)$ in experimental group whereas majority of the subjects had had duration of pain assessment rare as well as often (36.7\%) and minority of the subjects had daily pain assessment (3.3\%) in control group. 
$>$ Majority of the subjects had menstrual pain in experimental group as well as in control group $(100.0 \%)$.

$>$ Majority of the subjects had moderate menstrual pain $(53.3 \%)$ and minority of the subjects had mild pain $(20.0 \%)$ in experimental group whereas majority of the subjects had mild pain $(50.0 \%)$ and minority of the subjects had severe pain $(23.3 \%)$ in control group.

$>$ Majority of the subjects had menstrual pain in experimental group as well as in control group $(100.0 \%)$.

$>$ Majority of the subjects had no physical illness other than menstrual pain in experimental group as well as in control group $(100.0 \%)$.

$>$ In experimental group the paired t test value(9.10) was more than the paired test value of control group0.19. Hence acupressure was effective.

$>$ The chi square value was significant for religion, parents' monthly income, food habits, family history of dysmenorrhea, menstrual bleeding and duration of pain assessment.

\section{NURSING IMPLICATIONS OF THE STUDY}

The researcher had drawn the following implications from the studies which provide vital concern to the field of nursing practice, nursing education, nursing administration and nursing research.

\section{NURSING PRACTICE}

Nursing personnel should develop in-depth knowledge about primary dysmenorrhea and its impact on quality of life of adolescent girls. Nurses should be knowledgeable regarding the benefits of acupressure on dysmenorrhea. Midwifery nurses should encourage the adolescent girls to practice Acupressure in reducing dysmenorrhea.

\section{NURSING EDUCATION:}

Nurse educators should be equipped with knowledge regarding the techniques of acupressure. Conduct student's educational programmes for students regarding acupressure therapy for dysmenorrhea. Strengthen the curriculum of students to extend their knowledge and skills in various modalities of therapies.

\section{NURSING ADMINISTRATION}

Nurse administrator should assist in implementing public health awareness campaign in schools aimed at reducing dysmenorrhea pain. Nurse administrators should be able to make judgments as to which intervention helps in reducing dysmenorrhea. Public information programmes should be designed by nurses to encourage acupressure among adolescent girls to reduce dysmenorrhea.

\section{NURSING RESEARCH}

Research in acupressure will support the basic importance of the reduction of pain during dysmenorrhea and supportive evidence regarding effectiveness of acupressure. Research related to utility of acupressure for different age group and also different kind of physical problems. Thus promoting the utilization of the research findings by the health provider in the delivery of comprehensive health of the humans.

\section{RECOMMENDATIONS}

$>$ A study can be conducted on large samples may help to draw conclusions that are more definite and generalize to a larger population.

A comparative study can be conducted to evaluate the effectiveness of acupressure with other nonpharmacological measures such as abdominal massage for dysmenorrhea.

A study can be conducted to evaluate the effectiveness of acupressure for dysmenorrhea among women in all reproductive age group.

A study can be undertaken among teenage girls residing in hostel.

- A cohort study can be conducted to compare the acupressure on dysmenorrhea for three consecutive menstrual cycles

\section{LIMITATIONS}

$>$ The study was confined to small number of subjects, which limit the generalization.

$>$ The study was limited to selected areas

> The study was limited only to the students who were studying in Pre University College.

\section{REFERENCES}

1. Goswami Y.P, Dr. Jayalakshmi L.S, Dr. Mathur D.M. A Study to Assess the Effectiveness of Structured Teaching Programme on Knowledge regarding Substance Abuse among Adolescents at Selected Nursing Colleges of Udaipur District, Rajasthan, India. International Journal of Scientific and Research Publications, 2015 February [cited 26-05-2018]; 5(2); 2250-3153. Available from: http://www.i jsrp.org /researchpaper-0215/ijsrp-p38103pdf. 
2. Ramos M. M, Sebastian R. A. Adolescent substance use: Assessing the knowledge, attitudes, and practices of a school-based health center workforce. Journal of Substance Abuse, 2017 [cited 26-6-2018]; 38(2); 230-236. Available from https://www.tandfonline.com/doi/abs/ 10.1080/08897077.2017.1287149?journalCode=w sub20.

3. Hiremath. P, Mohite V.R Descriptive Study to Assess the Knowledge and Attitude on Ill Effects of Alcohol among Nursing Students in a Selected College at Karad. International Journal of Innovative Research and Development, 2016 April [cited 26-6-2018]; 5(5), 2278 0211.Availablefrom:file:///C:/Users/HP\%20PcDo wnloads /KnowledgeandAttitudeonIll Effects.pdf

4. Nayak D. A descriptive study- Knowledge and Practice of Substance Abuse Among the Adolescents Group. International Journal of Nursing Education and Research, 2016[cited 26-62018]; 4(2), 2454-2660 (Online), 2347-8640 (Print). Available from http:// ijneronline.com/ Abstract View.aspx? PID = 2016-4-2-7
5. Mendagudli V.G, Vijayalakshmi.K.A Descriptive Study on Attitude and Practice Towards Alcoholism among Adolescents,2017[cited 26-62018];5(1),2347-8632 (Print)

2454-2652(Online).Available from http://ijanm.com/HTMLPaper.aspx?Journal= International \%20Journal\%20of\%20Advances\%20in\%20Nursi ng\%20Management ;PID=2017-5-1-13

6. Jasdeep K, Kiranjit K.A Descriptive study to assess the knowledge regarding substance abuse among adolescent students of selected schools in Amritsar, Punjab with a view to develop information booklet. Asian Journal of Nursing Education and Research, 2015 [cited 26-62018];5(4):2231-1149(Print) ,2349-2996(Online). Available from http://ajner.com /HTMLPaper.aspx ?Journal =Asian\%20Journal $\% 20$ of\%20Nursing\%20Education $\% 20$ and\%20Research;PID=2015-5-4-4

7. Matthew. S. A. A Study to assess the knowledge and attitude regarding psycho active substances use among adolescents groupin Basaveshwara College, Rajajinagar, Bangalore 